ARTICLE

https://doi.org/10.1038/s41467-019-12440-x

\title{
Concerted dynamics of metallo-base pairs in an A/B-form helical transition
}

Olivia P. Schmidt', Simon Jurt', Silke Johannsen $\circledast^{1}{ }^{1}$, Ashkan Karimi', Roland K.O. Sigel ${ }^{1} \&$ Nathan W. Luedtke ${ }^{1 \star}$

Metal-mediated base pairs expand the repertoire of nucleic acid structures and dynamics. Here we report solution structures and dynamics of duplex DNA containing two all-natural C-Hgll-T metallo base pairs separated by six canonical base pairs. NMR experiments reveal a 3:1 ratio of well-resolved structures in dynamic equilibrium. The major species contains two (N3) $\mathrm{T}-\mathrm{Hg}^{\mathrm{II}}-(\mathrm{N} 3) \mathrm{C}$ base pairs in a predominantly B-form helix. The minor species contains (N3)T-Hgll-(N4)C base pairs and greater A-form characteristics. Ten-fold different ${ }^{1} \mathrm{~J}$ coupling constants $\left({ }^{15} \mathrm{~N},{ }^{199} \mathrm{Hg}\right)$ are observed for $(\mathrm{N} 3) \mathrm{C}-\mathrm{Hg}{ }^{11}(114 \mathrm{~Hz})$ versus $(\mathrm{N} 4) \mathrm{C}-\mathrm{Hg}{ }^{\|}$ $(1052 \mathrm{~Hz})$ connectivities, reflecting differences in cytosine ionization and metal-bonding strengths. Dynamic interconversion between the two types of $\mathrm{C}-\mathrm{Hg}^{\prime \prime}-\mathrm{T}$ base pairs are coupled to a global conformational exchange between the helices. These observations inspired the design of a repetitive DNA sequence capable of undergoing a global B-to-A-form helical transition upon adding $\mathrm{Hg}^{\prime \prime}$, demonstrating that $\mathrm{C}-\mathrm{Hg}{ }^{\prime \prime}-\mathrm{T}$ has unique switching potential in DNA-based materials and devices. 
$\mathrm{T}$ ransitions between $\mathrm{A}$ - and $\mathrm{B}$-form duplexes were discovered by Franklin and Gosling when conducting X-ray fibre diffraction analyses under various humidities ${ }^{1}$. In solution, protein binding reactions can also partially dehydrate duplex DNA, giving global A-form viral genomes ${ }^{2}$, as well as local A-form perturbations at specific binding sites ${ }^{3}$. Small molecules such as polyamines ${ }^{4}$, aminoglycosides ${ }^{5,6}$, hexaamminecobalt $(\mathrm{III})^{7}$, and cisplatin ${ }^{8,9}$ can induce local $\mathrm{B} \rightarrow \mathrm{A}$ transitions via mechanisms independent of global changes in hydration and water activity. The binding of metal ions to discreet coordination sites ${ }^{10}$ in nucleic acids can be coupled to the (re)folding of DNA and RNA molecules ${ }^{11-16}$ that activate DNAzymes ${ }^{17,18}$, ribozymes $^{19,20}$, riboswitches ${ }^{21-23}$, and DNA-based materials ${ }^{24-31}$ '. Previous studies mostly focused on characterizing the changes in structure and function of metal-bound versus metal-free (apo) nucleic acids. Here we report the structures and dynamics of two interconverting structures of the same metallo duplex, where local changes in metal-nucleobase ionization and isomerization are directly coupled to a global conformational exchange. This observation, together with the structural differences between metal-bound and apo duplex structures, enabled our design and identification of a duplex DNA containing $15 \mathrm{C}-\mathrm{T}$ mismatches that exhibits a global $\mathrm{B} \rightarrow \mathrm{A}$ helical transition upon adding $\mathrm{Hg}^{\mathrm{II}}$.

Transition metal ions participate in reversible binding interactions between opposing nucleobases ${ }^{32-37}$. T-HgII-T provided the first such example of an all-natural metal-mediated base pair composed of a pyrimidine-pyrimidine mismatch and a transition metal ion ${ }^{38-40}$. T-HgII-T base pairs exhibit very high kinetic and thermodynamic stabilities ${ }^{41-43}$, and can serve as functional mimics of T-A by causing enzymatic misincorporation of dTTP across from thymidine to give $\mathrm{T}^{-} \mathrm{Hg}^{\mathrm{II}}-\mathrm{T}$ in vitro ${ }^{44}$ and possibly in vivo ${ }^{44,45}$. NMR studies confirmed early predictions that $\mathrm{Hg}^{\mathrm{II}}$ binds to $\mathrm{T}-\mathrm{T}$ mismatches via $\mathrm{N} 3$ coordination of two deprotonated thymidine residues $^{46}$. Structurally analogous $\mathrm{C}-\mathrm{Ag}^{\mathrm{I}}$-C base pairs have also been reported ${ }^{47}$, and in both these cases, little or no impact on the global structure of the B-form duplex was reported ${ }^{47-49}$.

$\mathrm{C}-\mathrm{Hg}^{\mathrm{II}}$ - $\mathrm{T}$ is a newly discovered, all-natural metallo base pair for which relatively little information is available ${ }^{32,50,51}$. Using fluorescent nucleobase analogues and ${ }^{1} \mathrm{H}$ NMR spectroscopy, we recently reported stoichiometric, high affinity binding of $\mathrm{Hg}^{\mathrm{II}}$ to DNA duplexes containing C-T mismatches ${ }^{51}$. Conducted in parallel, crystal screening of various oligonucleotides and metal ions produced an X-ray structure of a short (8-mer), A-form DNA sequence containing two $\mathrm{C}-\mathrm{Hg}^{\mathrm{II}}-\mathrm{T}$ base pairs with an unexpected metal binding mode involving the exocyclic amine (N4) of a deprotonated cytosine "C" residue and (N3) of thymine "T" (Fig. 1) ${ }^{50}$. This coordination mode was in contrast to a preliminary proposal for $(\mathrm{N} 3) \mathrm{T}-\mathrm{Hg}_{\mathrm{II}}-(\mathrm{N} 3) \mathrm{C}$ coordination based on structural homology with $\mathrm{T}-\mathrm{Hg}^{\mathrm{II}}$ - $\mathrm{T}$ and small increases in thermal stabilities of duplexes containing C-T mismatches after

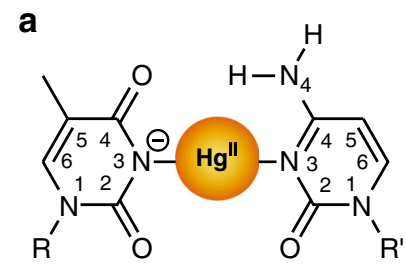

(N3)T-Hg"-(N3)C b

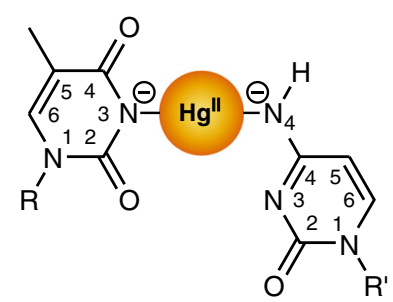

(N3) T-Hg"-(N4)C
Fig. 1 Proposed $\mathrm{C}-\mathrm{Hg}^{\mathrm{Il}}-\mathrm{T}$ binding modes. a, (N3) $\mathrm{T}-\mathrm{Hg} \mathrm{H}_{-}(\mathrm{N} 3) \mathrm{C}$ coordination based on structural homology with $\mathrm{T}-\mathrm{Hg}^{11}-\mathrm{T}^{32}$ and $\mathbf{b}$, (N3)T-Hg ${ }^{\prime \prime}-(\mathrm{N} 4) \mathrm{C}$ metal binding mode found in a short, A-form duplex DNA ${ }^{50}$ adding $\mathrm{Hg}^{\mathrm{II}}$ (Fig. 1) ${ }^{32}$. The global A-form structure observed in the crystal structure was inconsistent with circular dichroism (CD) data of slightly longer, 14-21-mer duplexes containing one or two $\mathrm{C}-\mathrm{Hg}^{\mathrm{II}}$-T base pairs ${ }^{51}$. The $\mathrm{CD}$ spectra suggested $\mathrm{B}$-form helices, and little-to-no changes in their global conformation upon adding $\mathrm{Hg}^{\mathrm{II}}$. The metal binding mode(s) and global structural characteristics of duplex DNA containing C- $\mathrm{Hg}^{\mathrm{II}}-\mathrm{T}$ base pairs in solution were therefore unclear.

Here we report a detailed NMR study using ${ }^{15} \mathrm{~N}$-labelled DNA and ${ }^{199} \mathrm{Hg}$ enriched mercury salts to determine the solution structures and dynamics of $\mathrm{C}-\mathrm{Hg}^{\mathrm{II}}-\mathrm{T}$ base pairs in duplex DNA. Unlike previous examples of metal-mediated base pairs, $\mathrm{C}-\mathrm{Hg}_{\mathrm{II}} \mathrm{T}$ exhibits two types of covalent connectivities that are dynamically coupled via a global conformational change in helical structure. A palindromic, 14-mer duplex with two $\mathrm{C}-\mathrm{Hg}^{\mathrm{II}}-\mathrm{T}$ sites separated by six canonical base pairs $\left(\mathrm{ODN}^{1}\right.$, Fig. 2a, Supplementary Table 1, and Supplementary Figs. 1,2) exists as a 3:1 mixture of welldefined duplexes in dynamic equilibrium. Both structures exhibit groove and rise dimensions intermediate between ideal A- and Bform helices. The most abundant duplex contains (N3)T-HgII(N3)C connectivity and mostly B-form helical characteristics, whereas the minor species contains $(\mathrm{N} 3) \mathrm{T}-\mathrm{Hg}^{\mathrm{II}}-(\mathrm{N} 4) \mathrm{C}$ base pairs and more A-form characteristics. No indication of a third duplex containing one of each type of metallo base pair is evident, consistent with long-range conformational coupling between the two metal centres. Furthermore, the rate constants for nucleobase-metal-nucleobase isomerization $\quad\left(k_{\mathrm{forward}}=3.5 \mathrm{~s}^{-1}\right.$ and $k_{\text {reversed }}=7.7 \mathrm{~s}^{-1}$ ) measured using $\left[{ }^{15} \mathrm{~N},{ }^{1} \mathrm{H}\right]$-HSQC experiments are nearly identical to those of the global conformational exchange of duplex structures measured using $\left[{ }^{1} \mathrm{H},{ }^{1} \mathrm{H}\right]-\mathrm{NOESY}$ experiments $\quad\left(k_{\text {forward }}=4.3 \pm 0.6 \mathrm{~s}^{-1}, \quad k_{\text {reversed }}=8.8 \pm 0.9 \mathrm{~s}^{-1}\right)$. These results therefore support the coupling of metal-ligand isomerization reactions over long distances (> $20 \AA$ ) via a global conformational change of the double helix. Taken together with the greater A-form characteristics upon metal binding, these results suggest that placing numerous $\mathrm{C}-\mathrm{T}$ mismatches throughout a repetitive duplex sequence can facilitate a global $\mathrm{B} \rightarrow \mathrm{A}$ helical transition upon adding $\mathrm{Hg}^{\mathrm{II}}$. To test this possibility, we prepare and analyse a small library of hairpin duplex DNAs $(\mathrm{n}=$ 10) and identify a duplex sequence that adopts a global A-form structure upon adding stoichiometric $\mathrm{Hg}^{\mathrm{II}}$. This helical transition is rapid $(<30 \mathrm{~s})$ and fully reversible upon addition of $\mathrm{N}$-acetylcysteine in a cycle that can be repeated more than 10 times on a

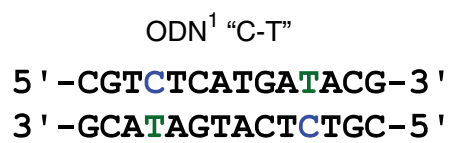

C

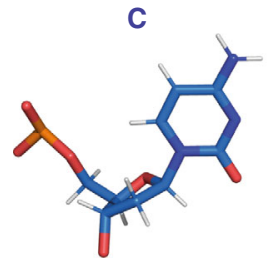

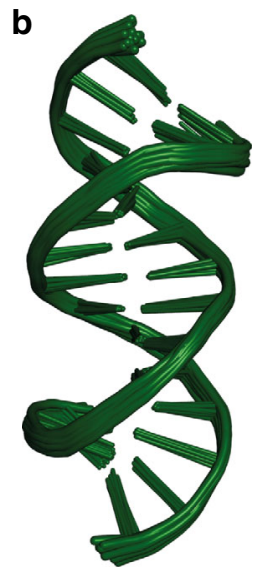

Fig. 2 Solution structure of metal-free duplex ODN " $\mathrm{C}-\mathrm{T}$ ". a DNA sequence. Blue and green bases indicate $\mathrm{C}-\mathrm{T}$ mismatches. $\mathbf{b}$ Overlay of 20 lowest energy structures. The structures were aligned to a representative model (\#1) containing fewest outliers in the geometric quality criteria. c Facial recognition of non-planar, C-T pair in model \#1 (PDB 6RLS) 
the same DNA. In addition to its broad implications in structural biology and biochemistry, such demand control of $\mathrm{B} \rightarrow \mathrm{A}$ and $\mathrm{A} \rightarrow \mathrm{B}$ helical switching may be utilized in the future development of advanced DNA-based materials and devices.

\section{Results}

Solution structure of $\mathrm{Hg}^{\mathrm{II}}$-free (apo) duplex $\mathrm{ODN}^{\mathbf{1}}$ “C-T". Our preliminary ${ }^{1} \mathrm{H}$ NMR and CD studies utilized a 14-mer $C_{2}$ symmetric, self-complementary sequence containing two C-T mismatches $\left(\mathrm{ODN}^{1} \text { "C-T", Fig. } 2 \mathrm{a}\right)^{51}$. This sequence exhibits a thermodynamically predictable ${ }^{52}$, two-state transition between single strand and duplex (Supplementary Fig. 2), as well as a ${ }^{1} \mathrm{H}$ NMR exchangeable imino region that is well resolved at $\mathrm{pH}=7$ (Supplementary Fig. 3). Here the full assignment of proton resonances was conducted by sequential walking along $\mathrm{H}^{\prime}$ and aromatic protons $\left(\mathrm{H}^{\prime}{ }_{\mathrm{n}} \rightarrow \mathrm{H} 6 / \mathrm{H} 8_{\mathrm{n}+1} \rightarrow \mathrm{H}^{\prime}{ }_{\mathrm{n}+1}\right)$ (Supplementary Fig. 14). As cross references for our assignments, $\mathrm{H} 2^{\prime}$ /aromatic, $\mathrm{H} 2^{\prime \prime}$ /aromatic $\quad\left(\mathrm{H} 2^{\prime} / \mathrm{H} 2^{\prime \prime} \mathrm{n} \rightarrow \mathrm{H} 6 / \mathrm{H} 8_{\mathrm{n}+1} \rightarrow \mathrm{H} 2^{\prime} / \mathrm{H} 2^{\prime \prime} \mathrm{n}_{+1}\right)$, and aromatic/aromatic $\left(\mathrm{H} 6 / \mathrm{H}_{\mathrm{n}} \rightarrow \mathrm{H} 6 / \mathrm{H} 8_{\mathrm{n}+1} \rightarrow \mathrm{H} 6 / \mathrm{H} 8_{\mathrm{n}+2}\right)$ regions in the $\left[{ }^{1} \mathrm{H},{ }^{1} \mathrm{H}\right]$-NOESY, $\left[{ }^{1} \mathrm{H},{ }^{1} \mathrm{H}\right]$-TOCSY $\left(\mathrm{H}^{\prime} \rightarrow \mathrm{H} 2^{\prime} / \mathrm{H} 2^{\prime \prime}\right)$ and $\left[{ }^{13} \mathrm{C},{ }^{1} \mathrm{H}\right]$-HSQC spectra (aliphatic and aromatic regions) were used. All signals of the duplex were well resolved and the sequential walk could be followed through the entire sequence. Models for the duplex were constructed based on 958 conformationally restrictive nuclear Overhauser effect (NOE) distance restraints (Table 1). The models did not contain any artificial constraints of co-planarity or hydrogen bonding for the C-T mismatches. Superimposition of the 20 lowest energy structures from 200 computed structures gave an overall root mean square deviation (r.m.s.d) of all heavy atoms of $0.74 \pm 0.26 \AA$, and $0.54 \pm$ $0.21 \AA$ for the C-T mismatch (Table 1, Fig. 2b). The central region forms a canonical B-form duplex, yet local perturbations about the non-coplanar C-T mismatches cause a $19 \pm 3^{\circ}$ bend in the helical axis at each mismatch. Given the high dynamics of this system and limitations of the modelling used, it is difficult to ascertain the exact pattern(s) of hydrogen bonding present in C-T mismatches. Consistent with an early NMR model, the mismatched pyrimidines are stacked inside the duplex in a co-facial orientation (Fig. 2c) ${ }^{53}$. Our structure suggests $\mathrm{C}-\mathrm{T}$ mismatches containing only one or two very weak hydrogen bonds. Evidence for weak hydrogen bonding is observed in the $\mathrm{C}-\mathrm{T}$ imino proton resonances at $10.9 \mathrm{ppm}$ that are broader than the imino resonances of an analogous duplex $\mathrm{ODN}^{2}$ "T-T" containing T-T mismatches, and much broader than those of $\mathrm{ODN}^{3}$ "G-T" containing G-T wobble base pairs (Supplementary Fig. 3). These observations correlated very well with the thermal stabilities of these duplexes $\left(\mathrm{T}_{\mathrm{m}} \mathrm{ODN}^{1}\right.$ "C $\left.\mathrm{C}-\mathrm{T} "=35^{\circ} \mathrm{C}\right), \quad\left(\mathrm{T}_{\mathrm{m}} \mathrm{ODN}^{2}\right.$ “T- $\left.\mathrm{T} "=38^{\circ} \mathrm{C}\right)$, and $\left(\mathrm{T}_{\mathrm{m}} \mathrm{ODN}^{3} \text { "G- } \mathrm{T}^{\prime \prime}=47^{\circ} \mathrm{C}\right)^{51}$, as well as other reported duplexes containing C-T, T-T, and G-T ${ }^{52,54,55}$. A weak interaction between $\mathrm{C}$ and $\mathrm{T}$ is further supported by the 10 -fold faster $\mathrm{Hg}^{\mathrm{II}}$ binding of $\mathrm{C}-\mathrm{T}$ versus $\mathrm{T}-\mathrm{T}$ mismatches ${ }^{51}$. Taken together with the axial bending in our structure, these results are consistent with the fact that $\mathrm{C}-\mathrm{T}$ mismatches are among the most thermodynamically destabilizing mismatches known in duplex DNA ${ }^{52,54,55}$.

Nucleobase-metal-nucleobase connectivity of C-HgII-T. Adding three equivalents of $\mathrm{Hg}^{\mathrm{II}}$ (1.5: 1.0 with respect to the number of mismatches) to duplex ODN 1 " $\mathrm{C}-\mathrm{T}$ " caused disappearance of the mismatched imino resonance at 10.9 ppm (Fig. 3a and Supplementary Fig. 3$)^{51}$. Similar results were obtained for the duplex $\mathrm{ODN}^{2}$ "T-T" containing two T-T mismatches (Supplementary Fig. 3). These results reflect specific binding reactions, since the addition of $\mathrm{Hg}^{\mathrm{II}}$ to an analogous duplex containing two G-T wobble base pairs $\left(\mathrm{ODN}^{3}\right.$ "G-T") caused no such deprotonation (Supplementary Fig. 3). $\left[{ }^{1} \mathrm{H},{ }^{1} \mathrm{H}\right]-\mathrm{NOESY}$ cross peaks between $\mathrm{NH}$ of thymidine and guanine residues, and between thymidine $\mathrm{NH}$ and $\mathrm{H} 2$ of adenine residues enabled assignment of all imino proton signals of $\mathrm{ODN}^{1}$ "C-T" in both the presence and absence of $\mathrm{Hg}$ II (Supplementary Figs. 4, 5). The imino proton resonances of the thymidine residues flanking the $\mathrm{C}$ - $\mathrm{T}$ mismatch exhibited the largest changes in chemical shifts upon $\mathrm{Hg}^{\mathrm{II}}$ addition, giving a final spectrum similar to that of $\mathrm{ODN}^{2}$ "T-T" containing the widely studied T-HgII-T base pairs (Supplementary Fig. 3, Supplementary Table 2) ${ }^{41,42,46,48,49}$.

To characterize the structure(s) of $\mathrm{C}-\mathrm{Hg}_{\mathrm{II}} \mathrm{T}$ base pairs, we synthesized a ${ }^{15} \mathrm{~N}$-labelled $\mathrm{ODN}^{1 \star}$ " $\mathrm{C}^{\star}-\mathrm{T}^{\star}$ " by synthetic incorporation of ${ }^{15} \mathrm{~N}$-labelled $\mathrm{C}$ and $\mathrm{T}$ residues at positions 4 and 11 in an otherwise unlabelled duplex. The splitting of the ${ }^{1} \mathrm{H}$ resonance at $10.9 \mathrm{ppm}$ by ${ }^{15} \mathrm{~N}(88 \mathrm{~Hz})$, and its disappearance upon adding $\mathrm{Hg}^{\mathrm{II}}$ (Fig. 3a) further confirmed its assignment as the mismatched thymidine $\mathrm{NH}$-resonance. The five ${ }^{15} \mathrm{~N}$-resonances in the absence of mercury were assigned by proton-coupled and protondecoupled ${ }^{15} \mathrm{~N}$ NMR spectra, ${ }^{1} J{ }^{1} \mathrm{H},{ }^{15} \mathrm{~N}$ coupling of thymidine $\mathrm{N} 3-\mathrm{H}$ and cytosine $\mathrm{NH}_{2}$ by heteronuclear single quantum coherence (HSQC), and ${ }^{3} J{ }^{1} \mathrm{H},{ }^{15} \mathrm{~N}$ - and ${ }^{2} J{ }^{1} \mathrm{H},{ }^{15} \mathrm{~N}$ coupling

Table 1 NMR restraints and statistics. ${ }^{a}$

\begin{tabular}{|c|c|c|c|}
\hline & Apo duplex & Hg" duplex (major form) & Hgll duplex (minor form) \\
\hline NOE-derived distance restraints ${ }^{b}$ & 958 & 646 & 640 \\
\hline Intra-nucleotide & 302 & 266 & 264 \\
\hline Inter-nucleotide $(i-j=1)$ & 566 & 306 & 302 \\
\hline Long-range $(i-j=\geq 2)$ & 90 & 74 & 74 \\
\hline $\mathrm{C}-\mathrm{T}, \mathrm{C}-\mathrm{Hg} \mathrm{g}^{\mathrm{Il}}-\mathrm{T}$ & 250 & 158 & 148 \\
\hline Repulsive & 0 & 0 & 0 \\
\hline NOE restraints per residue & 34.21 & 23.07 & 22.86 \\
\hline NOE violation $>0.2 \AA$ & 0 & 0 & 0 \\
\hline Dihedral restraints $b, c$ & 168 & 168 & 168 \\
\hline Dihedral violations $>5.0^{\circ}$ & 0 & 0 & 0 \\
\hline Hydrogen-bond restraints ${ }^{b, c}$ & 60 & 62 & 62 \\
\hline Planarity ${ }^{\mathrm{c}}$ & 24 & 24 & 24 \\
\hline \multicolumn{4}{|c|}{ r.m.s.d (all heavy atoms vs. best structure) } \\
\hline Overall & $0.74 \pm 0.26 \AA$ & $1.21 \pm 0.44 \AA$ & $1.09 \pm 0.36 \AA$ \\
\hline Helix & $0.83 \pm 0.29 \AA$ & $1.37 \pm 0.48 \AA$ & $1.21 \pm 0.40 \AA$ \\
\hline C-T, C-Hg"l-T base pairs & $0.54 \pm 0.21 \AA$ & $0.76 \pm 0.28 \AA$ & $0.75 \pm 0.29 \AA$ \\
\hline
\end{tabular}

aStatistics are given for the 20 lowest energy structures from 200 calculated structures. bexperimentally derived constraints (Supplementary Figs. 14, 16). CIntroduced constraints. The two additional hydrogen-bond restraints in the $\mathrm{Hg}^{\prime \prime}$-containing duplexes reflect N3-N3/N4 restraints for metal binding. The r.m.s.d. values are given as mean \pm standard deviation. Source data are provided as a Source Data file 

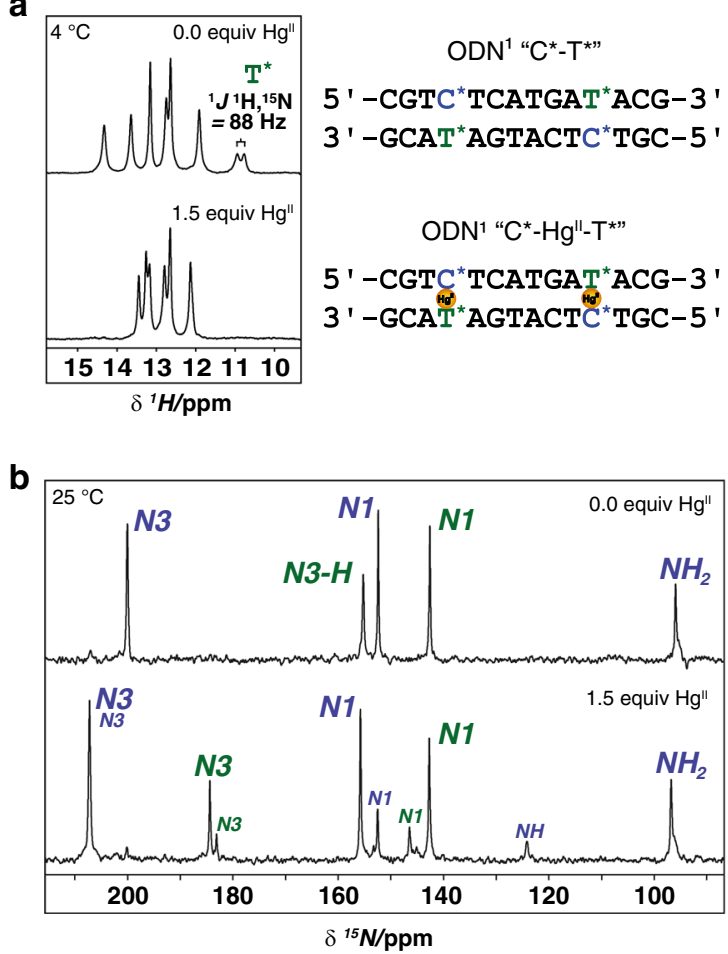

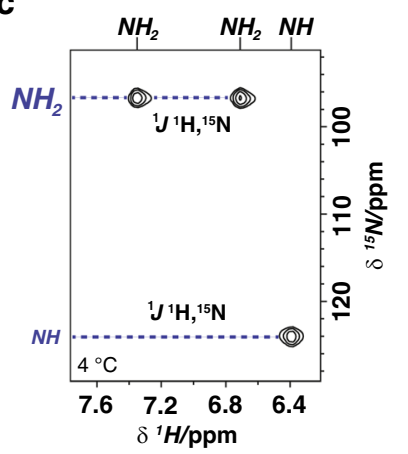

e

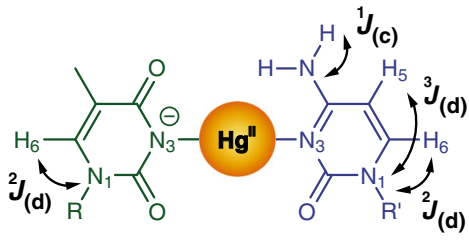

Major binding mode

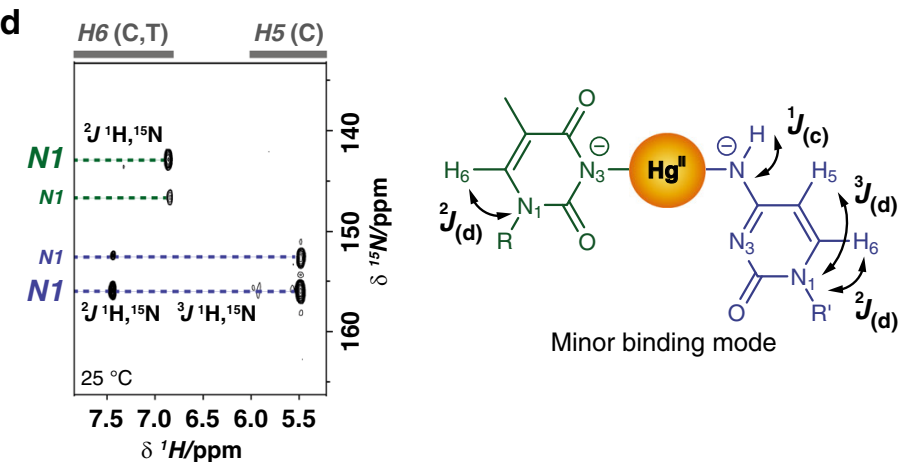

Fig. $3^{1} \mathrm{H}$ and ${ }^{15} \mathrm{~N}$ NMR spectra of duplex DNA upon formation of C-Hgll-T base pairs. a Imino proton region of ${ }^{1} \mathrm{H} N M R$ spectra of ODN ${ }^{1 \star}$ "C ${ }^{\star}-\mathrm{T}^{\star \prime \prime}$ in the absence and presence of 1.5 equiv of $\mathrm{Hg}^{\prime \prime}$ (where blue $\mathbf{C}^{\star}={ }^{15} \mathrm{~N}$-labelled $\mathrm{C}$, and green $\mathbf{T}^{\star}={ }^{15} \mathrm{~N}$-labelled $\mathrm{T}$ ). $\mathbf{b}^{15} \mathrm{~N}$ NMR spectra of ODN ${ }^{1 \star}$ " $\mathrm{C}^{\star}-\mathrm{T}^{\star}$ " before and after adding $\mathrm{Hg}^{\text {ll }}$. c ${ }^{1}{ }^{1} \mathrm{H}^{15} \mathrm{~N}$ coupling of cytosine (N4) $\mathrm{NH}_{2}$ major and of cytosine (N4) NH minor according to [ $\left.{ }^{15} \mathrm{~N},{ }^{1} \mathrm{H}\right]-\mathrm{HSQC}$. For full spectrum see Supplementary Fig. 9b. d Assignment of N1major and N1minor of thymidine and cytosine by ${ }^{3} \mathrm{~J}$ - and ${ }^{2} \mathrm{~J}$-coupling between $\mathrm{N} 1$ and $\mathrm{H} 5$ and/or $\mathrm{H} 6$ in the longrange $\left[{ }^{15} \mathrm{~N},{ }^{1} \mathrm{H}\right]-\mathrm{HSQC}$ spectrum. For full spectra see Supplementary Fig. 10a. e Major-and minor coordination modes of Hgll bound to C-T mismatches. DNA samples contained $1.0 \mathrm{mM} \mathbf{b}$ or $0.5 \mathrm{mM} \mathbf{a}, \mathbf{c}$, and $\mathbf{d}$ of duplex DNA and 1.5 equiv of Hgll (relative to the mismatches present) in aqueous buffer (200 mM NaClO $4,50 \mathrm{mM}$ cacodylic acid in $\mathrm{H}_{2} \mathrm{O} / \mathrm{D}_{2} \mathrm{O}(9: 1)$ at $\mathrm{pH}=7.8$ ). Blue labels indicate ${ }^{15} \mathrm{~N}$ resonances of $\mathrm{C}^{\star}$ and green labels indicate ${ }^{15} \mathrm{~N}$ resonances of $\mathrm{T}^{\star}$

between $\mathrm{N} 1$ and $\mathrm{H} 5$ and/or $\mathrm{H} 6$ by long-range $\left[{ }^{15} \mathrm{~N},{ }^{1} \mathrm{H}\right]$-HSQC (Supplementary Figs. 6, 7). After adding three equiv of $\mathrm{Hg}^{\mathrm{II}}(1.5$ : 1.0 with respect to the number of mismatches), two sets of ${ }^{15} \mathrm{~N}$ resonances were observed, corresponding to a "major" and a "minor" species in a 3:1 ratio (Fig. 3b). When adding only two equiv of $\mathrm{Hg}^{\mathrm{II}}$, these same signals were observed, in addition to those of unbound DNA, confirming that the minor species was not a result of any excess of $\mathrm{Hg}^{\mathrm{II}}$ (Supplementary Fig. 8). $\left[{ }^{15} \mathrm{~N},{ }^{1} \mathrm{H}\right]$-HSQC spectra allowed assignment of all ${ }^{15} \mathrm{~N}$ signals for both the major and minor complexes (Fig. 3c, d, Supplementary Figs. 9, 10. Disappearance of the N3-H cross peak in the ${ }^{1} J$ $\left[{ }^{15} \mathrm{~N},{ }^{1} \mathrm{H}\right]$-HSQC spectrum confirmed deprotonation of thymidine N3 upon addition of 1.5 equiv of $\mathrm{Hg}^{\mathrm{II}}$ (Supplementary Figs. 7, 8). The downfield shift of thymidine $\mathrm{N} 3$ major $(\Delta \mathrm{ppm}=+29)$ and $\mathrm{N} 3{ }^{\text {minor }}(\Delta \mathrm{ppm}=+28)^{46,56}$ suggested that direct $(\mathrm{N} 3) \mathrm{T}-\mathrm{Hg}^{\mathrm{II}}$ coordination was present in both binding modes (Fig. 3b, Supplementary Tables 3,4$) .{ }^{3}{ }^{1} \mathrm{H},{ }^{15} \mathrm{~N}$ - and ${ }^{2} J{ }^{1} \mathrm{H},{ }^{15} \mathrm{~N}$ coupling of $\mathrm{N} 1$ to $\mathrm{H} 5$ and/or $\mathrm{H} 6$ observed in long-range $\left[{ }^{15} \mathrm{~N},{ }^{1} \mathrm{H}\right]-\mathrm{HSQC}$ spectra allowed for assignment of $\mathrm{N} 1^{\text {major }}$ and $\mathrm{N} 1^{\text {minor }}$ resonances, as well as $\mathrm{H} 5$ and $\mathrm{H} 6$ protons for cytosine and $\mathrm{H} 6$ of thymidine (Fig. 3d and Supplementary Fig. 10). The appearance of a single cross peak in the direct $\left[{ }^{15} \mathrm{~N},{ }^{1} \mathrm{H}\right]$-HSQC spectrum at 124/6.39 ppm indicated deprotonation of cytosine (N4) $\mathrm{NH}^{\text {minor }}$ in the minor binding mode (Fig. 3c). The large downfield shift of cytosine (N4) $\mathrm{NH}^{\text {minor }}(\Delta \mathrm{ppm}=+28$, Fig. $3 \mathrm{~b}$, Supplementary Tables 3,4) and a doublet observed in the $\left[{ }^{15} \mathrm{~N},{ }^{1} \mathrm{H}\right]$-proton-coupled HSQC $(J=86 \mathrm{~Hz}$, Supplementary Fig. 9c) further suggested displacement of one $(\mathrm{N} 4) \mathrm{NH}_{2}$ proton by $\mathrm{Hg}^{\mathrm{II}}$ and direct $\mathrm{Hg}^{\mathrm{II}}$ coordination to $\mathrm{N} 4$ in the minor species. An NOE-cross peak between (N4) $\mathrm{NH}^{\text {minor }}$ to cytosine H5 (6.52/ $5.48 \mathrm{ppm}$ at $25^{\circ} \mathrm{C}$ ) confirmed this ${ }^{15} \mathrm{~N}$-resonance assignment (124 ppm) as being the deprotonated exocyclic amine of cytosine (Supplementary Fig. 11). ${ }^{3}{ }^{1} \mathrm{H},{ }^{15} \mathrm{~N}$ coupling of the ${ }^{15} \mathrm{~N}$-signal at $207 \mathrm{ppm}$ to (N4) $\mathrm{NH}^{\text {minor, }}$, as well as to $(\mathrm{N} 4) \mathrm{NH}_{2}{ }^{\text {major }}$ was observed in a band-selective, long-range $\left[{ }^{15} \mathrm{~N},{ }^{1} \mathrm{H}\right]$-HSQC (Supplementary Fig. 10b). This allowed assignment of the overlapping ${ }^{15} \mathrm{~N}$-resonances of the $\mathrm{N} 3^{\text {major }}$ and $\mathrm{N} 3^{\text {minor }}$ of cytosine. It was still unclear, however, if $\mathrm{Hg}^{\mathrm{II}}$ was directly coordinated to cytosine N3 $3^{\text {major }}$

To unambiguously determine metal-nucleobase connectivities $^{57}$, we monitored changes in the ${ }^{15} \mathrm{~N}$ NMR spectrum of $\mathrm{ODN}^{1 *}$ " $\mathrm{C}^{*}$ - $\mathrm{T}^{\star}$ " upon addition of ${ }^{199} \mathrm{Hg}$-isotopically enriched $(79 \%) \mathrm{Hg}\left(\mathrm{ClO}_{4}\right)_{2}$ (Fig. 4a). In the major binding mode, the N3resonances for both cytosine and thymidine appeared as doublets, thereby revealing their direct coordination to $\mathrm{Hg}^{\mathrm{II}}$ (Fig. 4a). The large ${ }^{1} J{ }^{15} \mathrm{~N},{ }^{199} \mathrm{Hg}$ coupling constant of $1095 \mathrm{~Hz}$ for thymidine $\mathrm{Hg}^{\mathrm{II}}-\mathrm{N} 3^{\text {major }}$ is consistent with $\mathrm{T}(\mathrm{N} 3)-\mathrm{Hg}^{\mathrm{II}}$ binding reported for a $\mathrm{T}-\mathrm{Hg}^{\mathrm{II}}-\mathrm{T}$ dinucleoside complex measured in d6-DMSO ${ }^{57}$. Cytosine $\mathrm{N}^{\text {major }}-\mathrm{Hg}_{\mathrm{II}}$ exhibited a much smaller coupling constant ${ }^{1} J{ }^{15} \mathrm{~N},{ }^{199} \mathrm{Hg}=114 \mathrm{~Hz}$ (Fig. 4a), consistent with a longer, weaker bond. A doublet with a coupling constant ${ }^{1} J$ ${ }^{15} \mathrm{~N},{ }^{199} \mathrm{Hg}=1052-1063 \mathrm{~Hz}$ confirmed direct $\mathrm{Hg}^{\mathrm{II}}$ coordination to cytosine (N4)NH $\mathrm{NH}^{\text {minor }}$ (Fig. 4a, b). This larger coupling constant is consistent with a stronger, shorter bond for $\mathrm{Hg}^{\mathrm{II}}-\mathrm{C}$ (N4) versus $\mathrm{Hg}^{\mathrm{II}}-\mathrm{C}(\mathrm{N} 3)$. Further support of our assignments was observed in ${ }^{1} \mathrm{H},{ }^{199} \mathrm{Hg}$ through-bond coupling with ${ }^{2} J{ }^{1} \mathrm{H},{ }^{199} \mathrm{Hg}$ 
a

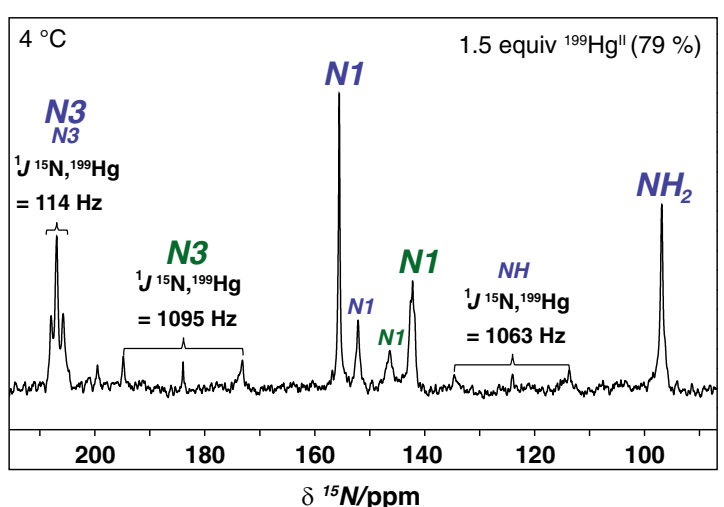

b

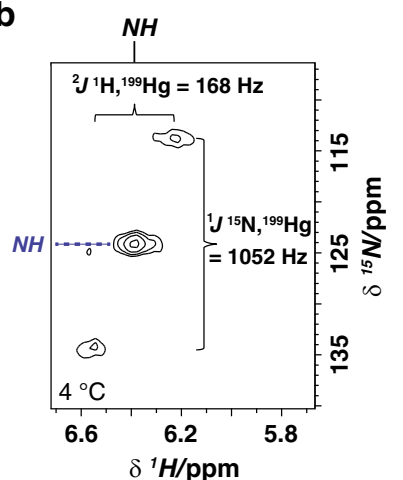

C $\quad \mathrm{NH}_{2} \mathrm{NH}$

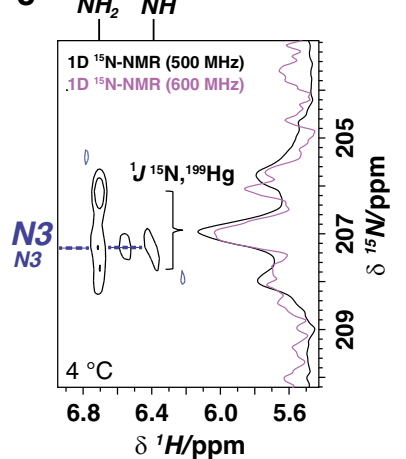

d

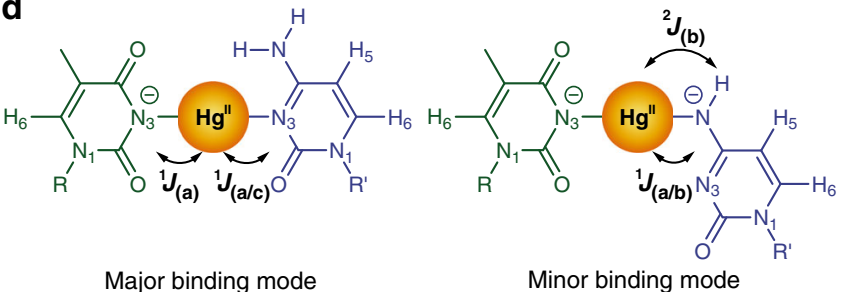

Fig. 4 Nucleobase-metal-nucleobase connectivity of $\mathrm{C}-\mathrm{Hg}{ }^{I I}-\mathrm{T}$ base pairs. a ${ }^{15} \mathrm{~N} N M R$ of ODN ${ }^{1 \star}$ " $\mathrm{C}^{\star}-\mathrm{T}^{\star}$ " in the presence of 1.5 equiv of ${ }^{199} \mathrm{Hg}$-enriched $\mathrm{Hg}\left(\mathrm{ClO}_{4}\right)_{2}$ (79\% enriched see Supplementary Fig. 13). b ${ }^{1} \mathrm{~J}^{15} \mathrm{~N},{ }^{199} \mathrm{Hg}$ and 2) ${ }^{1} \mathrm{H},{ }^{199} \mathrm{Hg}$ coupling according to $\left[{ }^{15} \mathrm{~N},{ }^{1} \mathrm{H}\right]-\mathrm{HSQC}$. For full spectra see Supplementary Fig. 12b. c ${ }^{1 / 15} \mathrm{~N},{ }^{199} \mathrm{Hg}$ coupling between cytosine $\mathrm{N} 3^{\text {major }}$ and ${ }^{199} \mathrm{Hg}$ observed in the band-selective, long-range $\left[{ }^{15} \mathrm{~N},{ }^{1} \mathrm{H}\right]-\mathrm{HSQC}$ spectrum. For full spectrum see Supplementary Fig. 12c. d Summary of major- and minor coordination complexes in duplex DNA and the observed couplings. DNA samples contained $1 \mathrm{mM}$ duplex DNA and $3 \mathrm{mM}{ }^{199} \mathrm{Hg}$ enriched $\mathrm{Hg}\left(\mathrm{ClO}_{4}\right)_{2}$. Blue labels indicate ${ }^{15} \mathrm{~N}$ resonances of $\mathrm{C}^{\star}$ and green labels indicate ${ }^{15} \mathrm{~N}$ resonances of $\mathrm{T}^{\star}$

$=168 \mathrm{~Hz}$ in the $\left[{ }^{15} \mathrm{~N},{ }^{1} \mathrm{H}\right]-\mathrm{HSQC}$ (Fig. $4 \mathrm{~b}$ ), a value that was similar to reported ${ }^{1} \mathrm{H},{ }^{199} \mathrm{Hg}$ coupling across nitrogen in unrelated systems measured in d6-DMSO or $\mathrm{CDCl}_{3}^{58-60}$. Splitting of the correlation between cytosine $\mathrm{N} 3^{\text {major }}$ and (N4) $\mathrm{NH}_{2}$ major in the band-selective, long-range $\left[{ }^{15} \mathrm{~N},{ }^{1} \mathrm{H}\right]-\mathrm{HSQC}$ further confirmed our assignment of $\mathrm{N} 3^{\text {major }}$ of cytosine (Fig. 4c). These data provide ${ }^{1} J{ }^{15} \mathrm{~N},{ }^{199} \mathrm{Hg}$ coupling constants in aqueous solutions, as well as cytosine $\mathrm{N} 3, \mathrm{Hg}^{\mathrm{II}}$ and cytosine $\mathrm{N} 4, \mathrm{Hg}^{\mathrm{II}}{ }^{1} \mathrm{~J}$ ${ }^{15} \mathrm{~N},{ }^{199} \mathrm{Hg}$ coupling constants. Taken together, these results revealed that $\mathrm{Hg}^{\mathrm{II}}$ binds to cytosine via two distinct coordination modes in solution. The major species contained two identical and unambiguous $(\mathrm{N} 3) \mathrm{T}-\mathrm{Hg}^{\mathrm{II}}-(\mathrm{N} 3) \mathrm{C}$ base pairs, and the minor species two identical and unambiguous (N3)T-HgII-(N4)C base pairs. No evidence for a lower symmetry duplex containing one of each type of base pair was observed in any NMR experiment.

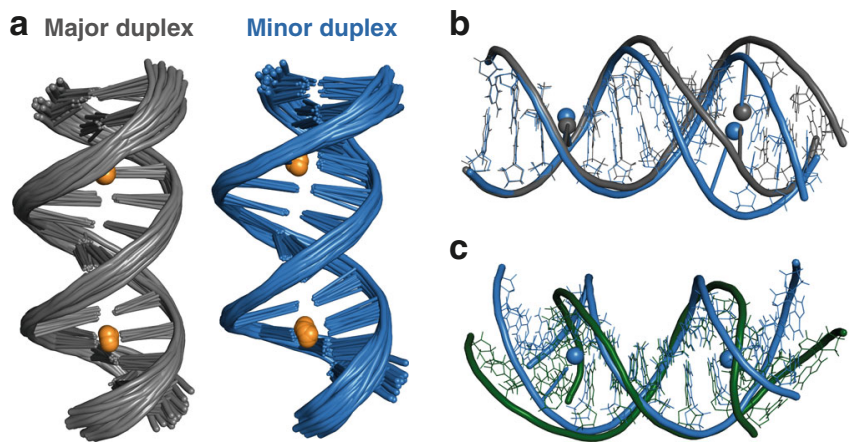

Fig. 5 Solution structures of ODN ${ }^{1}$ containing two $\mathrm{C}-\mathrm{Hg}^{\mathrm{II}}-\mathrm{T}$ base pairs and comparisons with the metal-free duplex. a Side-view overlay of the 20 lowest energy conformations for major- (grey) and minor (blue) metallo duplex structures. The 20 lowest energy structures were aligned to one representative model of each duplex containing zero outliers in the geometric quality criteria: for the major duplex, $\# 1$ of PDB $6 \mathrm{FY} 6$, and for the minor duplex \#6 of 6FY7. Hgll ions are depicted in gold. b Overlay comparison of these representative models of the major (grey) and minor (blue) duplexes. The duplexes were aligned by the end of each helix ( $\mathrm{C} 1$, $\mathrm{G} 2, \mathrm{~T} 3, \mathrm{~A} 26, \mathrm{C} 27, \mathrm{G} 28)$. The (N3)T-HgIl-(N4)C connectivity in the minor duplex makes this metallo-base pair more solvent accessible than (N3)T$\mathrm{Hg}^{\mathrm{II}}$-(N3)C, with a difference in solvent accessible surface area $(\triangle \mathrm{SASA})=$ $41 \AA^{2}$ as calculated by PyMOL. ${ }^{85}$ c Overlay comparison of representative minor metallo duplex (blue, model \#6) as compared to metal-free duplex (green, model \#1, PDB 6RLS). The duplexes were aligned by the center of each helix (A7, T8, A21, T22)

Global structures of duplexes containing C-HgII-T. Consistent with ${ }^{15} \mathrm{~N}$ NMR spectra (Figs. 3, 4), ${ }^{1} \mathrm{H}$ NMR experiments confirmed the presence of two $C_{2}$ symmetrical species (Supplementary Fig. 14). Proton resonance assignments and modelling for each duplex were conducted exactly the same as for the metal-free duplex. Aside from the first and last residues of the duplexes (C1 and G14), all signals of the major and minor metallo duplexes were well resolved and the sequential walk proceeded through the entire sequence (Supplementary Figs. 14, 15). Models for major and minor duplex were constructed based on 646 and $640 \mathrm{NOE}-$ derived conformationally restrictive distance restraints, respectively (Table 1). Superimposition of the 20 lowest energy structures of 200 computed structures gave an overall root mean square deviation (r.m.s.d) of all heavy atoms of $1.21 \pm 0.44 \AA$ for the major duplex and $1.09 \pm 0.36 \AA$ for the minor duplex (Fig. $5 \mathrm{a}$, Table 1).

As compared to the major duplex, the minor duplex exhibits more axial bending and a deeper, narrower major groove (Fig. 5b). The differences between the metal-bound and metal-free structures are also the greatest for the minor duplex (Fig. 5c). Inspection of the 20 lowest energy models for all three structures (apo, major metallo, and minor metallo) revealed a high frequency (65-100 \%) of an unusual, $\mathrm{O}^{\prime}$-endo sugar pucker at the cytosine residue of the $\mathrm{C}-\mathrm{T}$ and $\mathrm{C}-\mathrm{Hg}^{\mathrm{II}}-\mathrm{T}$ base pairs (Supplementary Table 6). Direct support for this was observed in the ${ }^{3} \mathrm{~J} \mathrm{H1}{ }^{\prime}, \mathrm{H}^{\prime}$ coupling constant for the $\mathrm{Hg}^{\mathrm{II}}$-coordinated cytosine residue ${ }^{3} \mathrm{~J}$ $\mathrm{H} 1^{\prime}, \mathrm{H} 2^{\prime}=6.5 \mathrm{~Hz}$ ) in the major structure (Supplementary Table 5, Supplementary Fig. 17). Using the Karplus equation (Supplementary Equation 1) ${ }^{61}$ a dihedral bond-angle of $\Phi_{12^{\prime}}=142^{\circ}$ was calculated, which is in excellent agreement with dihedral angles observed in the solution structure models $\left(\Phi_{12^{\prime}}=131^{\circ}\right)$ (Supplementary Fig. 18, Supplementary Equation 1) 61,62 $^{6}$ However, the apparent $\mathrm{O}^{\prime}$-endo sugar puckers present in all three structures likely reflect the averaged conformations of rapidly interconverting $\mathrm{C2}^{\prime}$ - and $\mathrm{C}^{\prime}$-endo sugar puckers that occur much faster than the time scale of these NMR measurements ${ }^{63-67}$. 
a
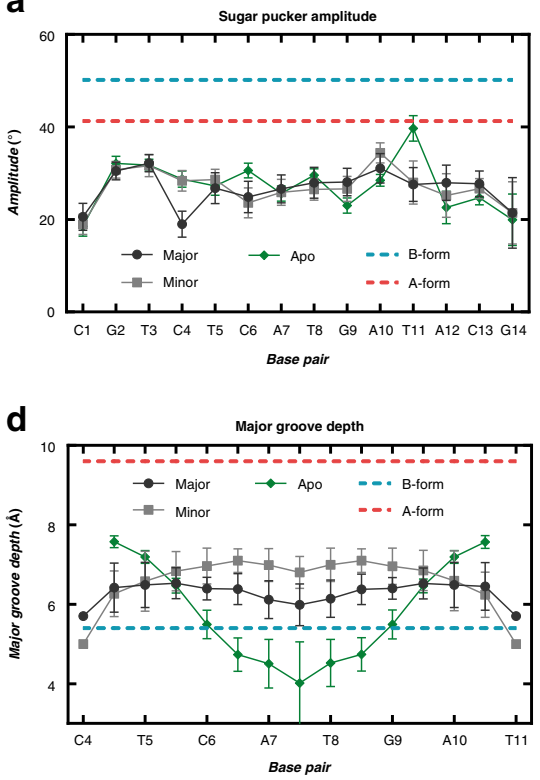

b

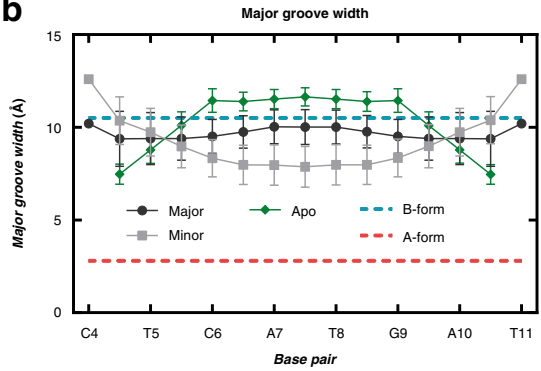

e

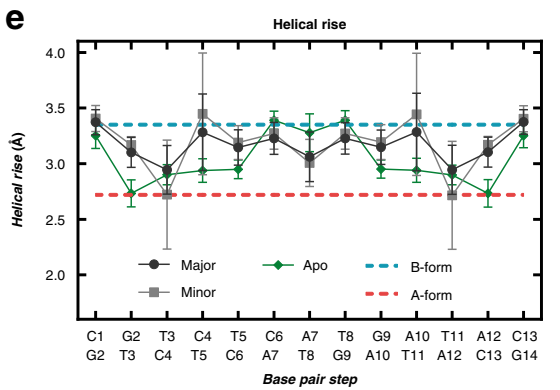

C

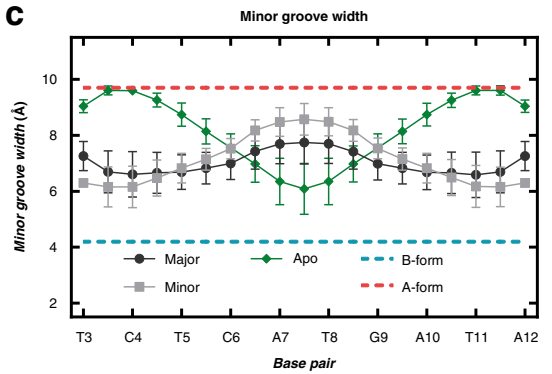

f

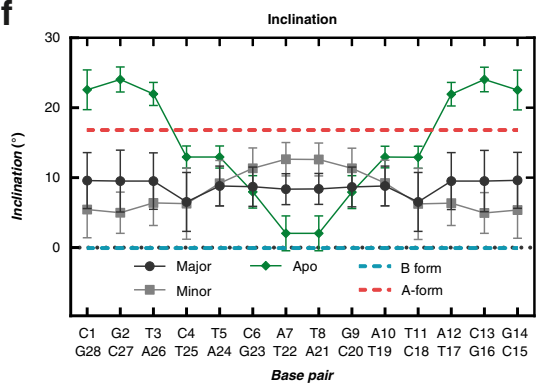

Fig. 6 Selected base pair and base pair step parameters of apo-, Hgll-bound major-, and Hgll-bound minor duplex structures. Parameters of apo (green diamonds, PDB 6RLS), Hgll-bound major (black circles, PDB 6FY6) and Hgll-bound minor (grey squares, PDB 6FY7) duplex structures were calculated using Curves $+{ }^{86}$ a Sugar pucker amplitude. b Major groove width. c Minor groove width. $\mathbf{d}$ Major groove depth. e Helical rise. $\mathbf{f}$ Inclination. The reference values for standard A- (red) and B-form (blue) duplex DNA were taken from (ref 86), which analyzed crystal structures of A-DNA (PDB 1d1388) and BDNA (PDB $1 b^{6} a^{66}$ ) dodecamers. Reported values represent the mean and standard deviation of the 20 lowest energy conformations for each structure. For additional analyses of base pair parameters see Supplementary Figs. 19 -22. Source data are provided as a Source Data file

Support for this conclusion can be found in the analyses of global parameters, where the sugar pucker amplitudes throughout all three duplexes were much smaller than both A-form and B-form duplexes (Fig. 6a). In contrast, nearly all other structural parameters including groove dimensions, twist and rise gave values intermediate between A- and B-form duplexes (Fig. 6b-f, and Supplementary Figs. 19-22) ${ }^{68}$.

Dynamics of major-minor metallo duplex interconversion. The presence of two individual sets of NMR signals, together with exchange cross peaks and exchange-mediated cross peaks between them (Supplementary Figs. 23-26 and Supplementary Figs. 36-38) indicated the presence of conformational changes with rates suitable for determination by standard NMR methods. To investigate the dynamic changes in local metal ion coordination, $\mathrm{z}-\mathrm{z}$ exchange $\left[{ }^{15} \mathrm{~N},{ }^{1} \mathrm{H}\right]$-HSQC spectra were measured ${ }^{69}$. With increasing delay time $\left(t_{m}\right)$, new exchange signals appeared (Fig. 7a, Supplementary Fig. 23). Global fitting of integrated peak volumes versus exchange delay times (Supplementary Equations 6-9) furnished rate constants of $k_{1}=3.5 \mathrm{~s}^{-1}$ and $k_{-1}=7.7 \mathrm{~s}^{-1}$ for the forward and reverse reactions of nucleobasemetal-nucleobase isomerization, respectively (Fig. 7a).

Single exchange signals in ROESY spectra were observed for the $\mathrm{Hg}^{\mathrm{II}}$-bound nucleosides as well as for sugar- and aromatic proton signals of various residues throughout the duplex (Supplementary Fig. 24). The same exchange signals were found in the $\left[{ }^{1} \mathrm{H},{ }^{1} \mathrm{H}\right]$-TOCSY spectrum in the $\mathrm{H} 1^{\prime} / \mathrm{H} 5$ region ( 5.0-6.2 ppm, Supplementary Fig. 25). Within that region, no protons belonged to the same spin system. The observed cross peaks therefore occurred by exchange rather than through-bond coupling. Exchange-mediated cross peaks were observed in the aromatic $\rightarrow \mathrm{H} 2^{\prime} / \mathrm{H} 2^{\prime \prime}$ region of the $\left[{ }^{1} \mathrm{H},{ }^{1} \mathrm{H}\right]$-NOESY spectrum (Supplementary Fig. 26), confirming the global nature of the conformational change. To evaluate the potential impact of variable ionic strength on the exchange rates, samples of the metallo duplex were prepared in the presence of $50 \mathrm{mM}, 200 \mathrm{mM}$ and $500 \mathrm{mM} \mathrm{NaClO}_{4}$. The overall exchange rates of interconversion between the two structures decreased with increasing ionic strength, but the ratio of the two structures remained the same (Supplementary Figs. 27-31). Likewise, pH-dependent measurements revealed slower overall exchange rates with increasing $\mathrm{pH}$ from $\mathrm{pH}$ 6-9 while maintaining the same ratio (Supplementary Figs. 32-35). The lower rates of exchange correlate with the increasing persistence length and therefore rigidity of the duplex with increasing $\mathrm{pH}$ and ionic strength ${ }^{70,71}$.

To determine rate constants of global interconversion of the two duplexes, we measured $\left[{ }^{1} \mathrm{H},{ }^{1} \mathrm{H}\right]$-NOESY spectra with various mixing times $\left(\mathrm{t}_{\mathrm{m}}\right)$ using samples prepared in the presence of $200 \mathrm{mM} \mathrm{NaClO}_{4}$ at $\mathrm{pH}=7.8$. Selected exchange cross peaks ('Aa' and 'aA', Supplementary Fig. 37) and exchange-mediated NOE cross peaks ('Ab' and ' $\mathrm{aB}$ ', Supplementary Fig. 38) at residues throughout the duplex were integrated, normalized to signal intensity at mixing time $=200 \mathrm{~ms}$, and plotted as a function of mixing time $\left(t_{m}\right)$ (Supplementary Table 7, Supplementary Figs. 39-42). For definitions of peak labels, see Supplementary Fig. 36. Exchange cross peaks were fit to Supplementary Equation 12 to determine the sum of rate constants $k_{1}+k_{-1}$ (Fig. 7b, Supplementary Fig. 39 and Supplementary Table 7). For signals having sufficient resolution of the diagonal peaks ('AA' and 'aa') for integration purposes, exchange cross peaks were normalized by aA $\left(t_{m}\right) /\left(A A\left(t_{m}\right)+a A\left(t_{m}\right)\right)$ and fit to Supplementary Equation 14 to determine individual rate constants $k_{1}$ and $k_{-1}$ (Fig. $7 \mathrm{~b}$ and Supplementary Fig. 41). Dividing exchange-mediated cross peaks ('Ab' and 'aB') by the sum with their corresponding NOE cross peak ('AB' and 'ab') allowed the determination of rate constants $k_{1}$ and $k_{-1}$ by fitting to Supplementary Equations 18 and 19 (Supplementary Fig. 42). The sum of rate constants $k_{1}+k_{-1}$ determined for the global conformational change according to exchange cross peaks $\left(10.5-15.0 \mathrm{~s}^{-1}\right)$, as well as the individual rate constants $k_{1}$ $\left(3.8-5.2 \mathrm{~s}^{-1}\right)$ and $k_{-1}\left(7.5-9.7 \mathrm{~s}^{-1}\right)$ independently determined 
a

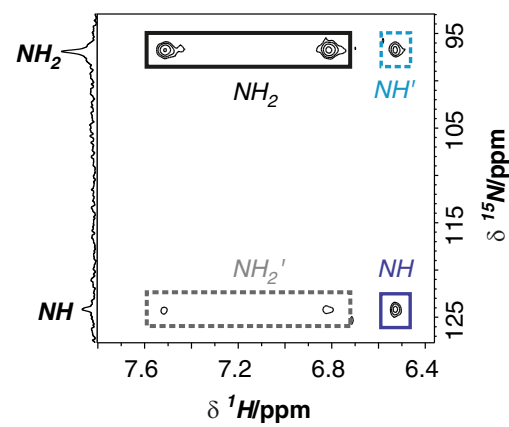

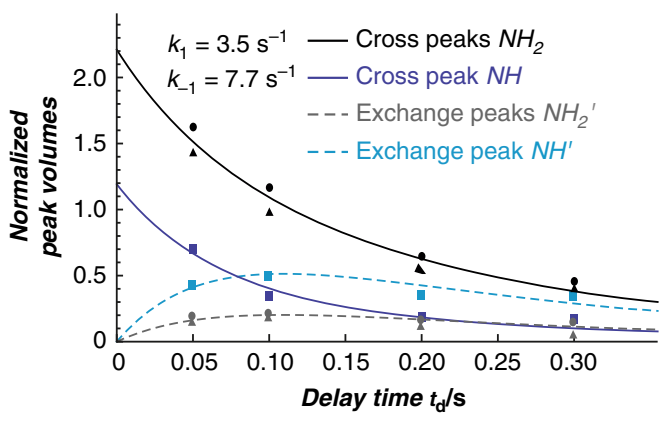

b
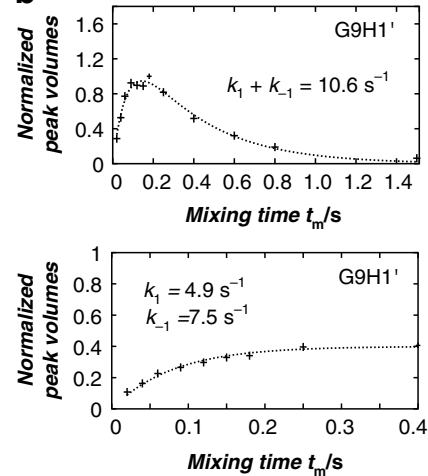

C
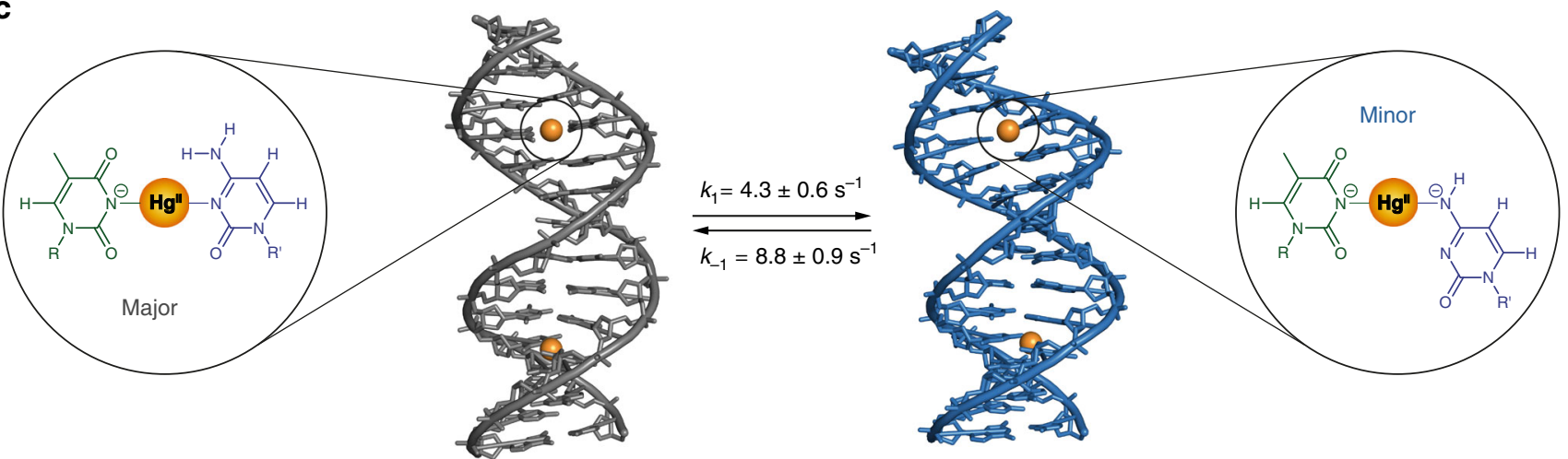

Fig. 7 Dynamic isomerization of duplex DNA containing two C-Hgll-T base pairs. a Dynamic changes in local metal ion coordination. Rate constants of interconversion were determined by plotting changes in cross peaks $\left(\mathrm{NH}_{2}\right.$ and $\left.\mathrm{NH}\right)$ and exchange cross peaks $\left(\mathrm{NH}_{2}{ }^{\prime}\right.$ and $\left.\mathrm{NH}^{\prime}\right)$ observed in $\mathrm{z}-\mathrm{z}$ exchange $\left[{ }^{15} \mathrm{~N},{ }^{1} \mathrm{H}\right]-\mathrm{HSQC}$ spectrum as a function of different delay times. Rate constants of interconversion were determined by global fitting of integrated peak volumes versus exchange delay times using Supplementary Equations 6-9, where $R_{1}, k_{1}$, and $k_{-1}$ were constrained as being equal for all four curves with the assumption that all proton- and nitrogen atoms have the same relaxation rate $\left(R_{1}\right)$ and that the $\mathrm{NH}$ proton is converted equally to both $\mathrm{NH}_{2}$ protons during the exchange. b Representative example $(\mathrm{G} 9 \mathrm{H} 1$ ') of duplex interconversion rate constants as determined by monitoring changes in exchange cross peaks and exchange-mediated NOE cross peaks in $\left[{ }^{1} \mathrm{H},{ }^{1} \mathrm{H}\right]$-NOESY spectra with various mixing times $\left(t_{\mathrm{m}}\right)$. At longer mixing times, a decrease in signal intensity was observed due to auto relaxation $\left(R_{1}\right)$. The sum of interconversion rate constants $\left(k_{1}+k_{-1}\right)$ was determined by fitting changes in cross peak intensity vs mixing time $\left(t_{m}\right)$ (Supplementary Equation 12). The individual rate constants of interconversion $\left(k_{1}\right.$ and $\left.k_{-1}\right)$ were determined by fitting (Supplementary Equation 14) cross peak intensities normalized by the intensities of diagonal peaks versus mixing times. See Supplementary Figs. 37,38 for $\left[{ }^{1} \mathrm{H},{ }^{1} \mathrm{H}\right]-\mathrm{NOESY}$ spectra, and Supplementary Figs. 39-42 for the same types of analyses at other positions. c Summary of major- and minor duplex structures, structures of the metallo base pairs they contain, and the rate constants of their exchange. Rate constants values are given as mean \pm standard deviation from 5 exchange cross peaks and exchange-mediated NOE cross peaks. The $\mathrm{Hg}^{\mathrm{Il}}$-ligand complexes present in the major species are net positive $(+1)$, whereas those of the minor species are neutral. The combined contributions of more favourable electrostatic interactions and near-canonical B-form helical structure present in the major species likely outweigh the stronger ligand-metal-ligand binding interactions present in the minor duplex

from exchange cross peaks and exchange-mediated cross peaks, were all in excellent agreement with rate constants determined for changes in metallo base pair structure $\left(k_{1}=3.5 \mathrm{~s}^{-1}, k_{-1}=\right.$ $7.7 \mathrm{~s}^{-1}$, Fig. 7a, Supplementary Table 7). Together with the absence of a third, lower symmetry duplex containing one of each type of metallo-base pair, these results revealed that dynamic changes in local metal-ligand isomerization were coupled to the global interconversion of the two duplex structures (Fig. 7c).

$\mathrm{Hg}^{\mathrm{II}}$-induced, conformational switching from B- to A-form. The long-range coupling ( $>20 \AA$ ) between the metal centres as well as the increased A-form characteristics in the centre region of the duplex upon metal binding, suggested that placing numerous $\mathrm{C}-\mathrm{T}$ mismatches throughout a repetitive duplex sequence could facilitate a global $\mathrm{B} \rightarrow$ A helical transition upon adding $\mathrm{Hg}^{\mathrm{II}}$. To test this possibility, we introduced C-T mismatches into $\left(\mathrm{G}_{4} \mathrm{C}_{4}\right)_{\mathrm{n}}$ type DNA sequences that are known to exhibit partial A-form characteristics ${ }^{50,72-74}$. To supress formation of intramolecular G-quadruplex structures that would otherwise interfere with intermolecular duplex formation of such repetitive sequences, we designed a small library of 120-mer DNA hairpins (Supplementary Table 8) containing the tetraloop sequence cGCTAg that is known to stabilize both RNA and DNA hairpins $^{75}$. To fold the hairpins, dilute solutions of DNA $(1 \mu \mathrm{M})$ were heated $\left(95^{\circ} \mathrm{C}, 5 \mathrm{~min}\right)$ and rapidly cooled on ice at $0^{\circ} \mathrm{C}$. Samples were then incubated with 0.0 or 1.5 equiv of $\mathrm{Hg}^{\mathrm{II}}$ (relative to number of C-T mismatches present) at $25^{\circ} \mathrm{C}$ for $3 \mathrm{~h}$ prior to their analysis. Gel electrophoresis revealed clean, intramolecular hairpin formation for most sequences in both the presence and absence of $\mathrm{Hg}^{\mathrm{II}}$, including our hit $\mathrm{ODN}^{13}$ (Supplementary Fig. 43). To screen for the induction of A-form structures by $\mathrm{Hg}^{\mathrm{II}}$, we used a fluorescent aminoglycoside binding assay $^{74}$. Aminoglycoside antibiotics exhibit a general selectivity for binding A-form over B-form helices ${ }^{6}$. Changes in the fluorescence anisotropy of a $40 \mathrm{nM}$ solution of a Neomycin-BODIPY conjugate "Neo-BODIPY"76 were therefore measured in the presence and absence of each DNA $(600 \mathrm{nM})$ pre-treated with $\mathrm{Hg}^{\mathrm{II}}$ (0.0 or 1.5 equiv per $\mathrm{C}-\mathrm{T}$ mismatch). No changes in 
anisotropy were observed upon addition of all hairpins in the absence of $\mathrm{Hg}^{\mathrm{II}}$, however, the pre-incubation of $\mathrm{ODN}^{13}$ with $\mathrm{Hg}^{\mathrm{II}}$ caused a 3.5-fold increase in fluorescence anisotropy of NeoBODIPY (Table 2). Titration of the ODN ${ }^{13}-\mathrm{Hg}^{\mathrm{II}}$ complex into solutions of Neo-BODIPY revealed an apparent dissociation constant $\left(K_{\mathrm{d}}\right)=1.4 \pm 0.7 \mu \mathrm{M}$ (Fig. 8a). This value is similar to the values reported for binding of neomycin to A-form, duplex RNA $^{77}$. The ternary complex formed between Neo-BODIPY and $\mathrm{ODN}^{13}-\mathrm{Hg}^{\mathrm{II}}$ was disrupted by the addition of unlabelled neomycin B (Supplementary Fig. 44), as well as $N$-acetylcysteine that sequesters HgII (Supplementary Fig. 45). These results demonstrate the reversibility of Neo-BODIPY binding, a lack of significant impact by the BODIPY tag, as well as the switch-like (on/ off) effect of $\mathrm{Hg}^{\mathrm{II}}$ binding to $\mathrm{ODN}^{13}$. The analogous hairpin containing $\mathrm{T}$-A base pairs $\left(\mathrm{ODN}^{14}\right)$ in place of $\mathrm{T}-\mathrm{C}$ mismatches exhibited no such behaviour (Table 2). These observations are confirmed using $\mathrm{CD}$ spectroscopy.

The $\left(\mathrm{G}_{3} \mathrm{C}_{3}\right)_{\mathrm{n}}$-containing hairpins $\mathrm{ODN}^{4}$ and $\mathrm{ODN}^{5}$ exhibited $\mathrm{CD}$ spectra consistent with previous publications ${ }^{72}$, having a double maximum at $260 \mathrm{~nm}$ and $280 \mathrm{~nm}$ (Fig. $8 \mathrm{~b}$ and Supplementary Fig. 46) that are thought to reflect a mixture of

\begin{tabular}{|c|c|c|c|}
\hline Name & DNA repeat sequence & no HgII & $+\mathbf{H g}^{\prime \prime}$ \\
\hline- & (Neo-BODIPY only) & $0.05 \pm 0.01$ & $0.05 \pm 0.01$ \\
\hline $\mathrm{ODN}^{4}$ & {$[\mathbf{C G G G C C C G G G C C}]_{4.5}$} & $0.05 \pm 0.01$ & $0.06 \pm 0.01$ \\
\hline ODN 5 & {$[\mathbf{T} G G G C C C \mathbf{C G G G C C C C}]_{3.5}$} & $0.05 \pm 0.01$ & $0.06 \pm 0.01$ \\
\hline ODN 6 & {$[\mathbf{C G G G}]_{14}$} & $0.05 \pm 0.02$ & $0.05 \pm 0.01$ \\
\hline $\mathrm{ODN}^{7}$ & {$[\mathbf{T C T} G G G C]_{8}$} & $0.04 \pm 0.01$ & $0.05 \pm 0.02$ \\
\hline ODN 8 & {$\left[\mathbf{T G G T G C C C C C G G ] _ { 5 }}\right.$} & $0.05 \pm 0.01$ & $0.04 \pm 0.01$ \\
\hline ODN $^{9}$ & {$[\mathbf{T} G G G T G G T C G C]_{5}$} & $0.05 \pm 0.01$ & $0.05 \pm 0.01$ \\
\hline $\mathrm{ODN}^{10}$ & {$[\mathbf{C G G G T G G C C G C}]_{5}$} & $0.04 \pm 0.01$ & $0.05 \pm 0.01$ \\
\hline $\mathrm{ODN}^{11}$ & {$[\mathbf{T G G G C G G T C G C}]_{5}$} & $0.05 \pm 0.01$ & $0.05 \pm 0.01$ \\
\hline $\mathrm{ODN}^{12}$ & {$\left[\mathbf{T C C T C G G T G G C ] _ { 5 }}\right.$} & $0.04 \pm 0.02$ & $0.05 \pm 0.01$ \\
\hline $\mathrm{ODN}^{13}$ & {$[\mathbf{T G G T C C C T C G G}]_{5}$} & $0.04 \pm 0.01$ & $0.14 \pm 0.01$ \\
\hline $\mathrm{ODN}^{14}$ & {$[\text { TGGTCCCTCGG }]_{5}$} & $0.04 \pm 0.01$ & $0.05 \pm 0.01$ \\
\hline
\end{tabular}

aBold bases indicate C-T mismatches. Italic bases in ODN14 indicate T-A base pairs. ${ }^{b} A l l$ samples contained $40 \mathrm{nM}$ of Neo-BODIPY, $600 \mathrm{nM}$ of DNA, and 0 or 1.5 equiv of $\mathrm{Hg}$ "l per C-T mismatch in an aqueous buffer containing $200 \mathrm{mM} \mathrm{NaClO}_{4}$ and $50 \mathrm{mM}$ cacodylic acid ( $\mathrm{pH}=$ 7.8). Averaged anisotropy values and standard deviations of three independent measurements are shown. Source data are provided as a Source Data file
A-form and B-form-like stacking of the guanine and cytosine nucleobases, respectively. The addition of $\mathrm{Hg}^{\mathrm{II}}$ had little-to-no impact on the CD spectra of hairpins $\mathrm{ODN}^{4-12}$ or $\mathrm{ODN}^{14}$ (Fig. 8b and Supplementary Fig. 46). However, addition of $\mathrm{Hg}^{\mathrm{II}}$ to hairpin $\mathrm{ODN}^{13}$ caused changes in its $\mathrm{CD}$ spectrum indicative of a global B- to A-form helical transition (Fig. 8c and Supplementary Fig. 47a) ${ }^{78}$. This $\mathrm{Hg}^{\mathrm{II}}$-induced conformational change exhibited a 1:1 stoichiometry between $\mathrm{Hg}^{\mathrm{II}}$ and the number of $\mathrm{C}-\mathrm{T}$ mismatches present (Supplementary Fig. 47b), was extremely rapid ( $<30 \mathrm{~s}$ to complete) and fully reversible upon addition of $\mathrm{N}$ acetylcysteine (Supplementary Fig. 47c). Given the relatively low G-quadruplex propensity of sequence $\mathrm{ODN}^{13}$, we were successful in preparing the corresponding intermolecular duplex lacking a hairpin turn. This simple duplex "ODN ${ }^{13} \mathrm{ds}$ " also exhibited a reversible, $\mathrm{Hg}^{\mathrm{II}}$-inducted switching between global B- and $\mathrm{A}$-form helices (Supplementary Fig. 48). By alternating between the addition of $\mathrm{Hg}^{\mathrm{II}}$ and $\mathrm{N}$-acetylcysteine, the helical switching cycle from B- to A-form, and A-form to B-form could be repeated more than 10 times on the same DNA (Supplementary Fig. 49).

\section{Discussion}

Here we report solution structures of $\mathrm{C}-\mathrm{Hg}^{\mathrm{II}}-\mathrm{T}$ base pairs. In addition to providing fundamental insights into $\mathrm{C}-\mathrm{Hg}_{\mathrm{II}} \mathrm{T}$ binding and dynamics, these results provide ${ }^{1} J{ }^{15} \mathrm{~N},{ }^{199} \mathrm{Hg}$ and ${ }^{2} J$ ${ }^{1} \mathrm{H},{ }^{199} \mathrm{Hg}$ coupling constants. Prior to these studies, little or no such information was available for these coupling constants in water ${ }^{46,47,58,79}$. Large differences in ${ }^{1} J{ }^{15} \mathrm{~N},{ }^{199} \mathrm{Hg}$ coupling constants for complexes containing (N3)C-HgII $(114 \mathrm{~Hz})$ versus (N4) $\mathrm{C}-\mathrm{Hg}$ II $(1052 \mathrm{~Hz})$ will provide a basis for future computational studies that address the relationships between coupling constants, ligand ionization and metal binding ${ }^{57}$.

Aside from the gain/loss of a proton from (N4)C, the major/ minor duplexes of $\mathrm{ODN}^{1}$ bound to $\mathrm{Hg}^{\mathrm{II}}$ are constitutional isomers with respect to each other. Isomerization-coupled conformational exchange between these structures was relatively slow on the chemical-shift NMR time scale, yet it was fast enough to allow direct characterization by monitoring changes in exchange cross peaks as a function of mixing time $\left(t_{m}\right)$. The rate constants of nucleobase-metal-nucleobase isomerisation $\left(k_{1}=3.5 \mathrm{~s}^{-1}\right.$ and $k_{-1}=7.7 \mathrm{~s}^{-1}$ ) were nearly identical to rate constants independently measured for the global conformational exchange of the two duplex structures $\left(k_{1}=4.3 \pm 0.6 \mathrm{~s}^{-1}, k_{-1}=8.8 \pm 0.9 \mathrm{~s}^{-1}\right)$. No evidence for a third duplex containing one of each type of metalbase pair was observed, giving further support for coupling between the metal centres via global conformational exchange. a

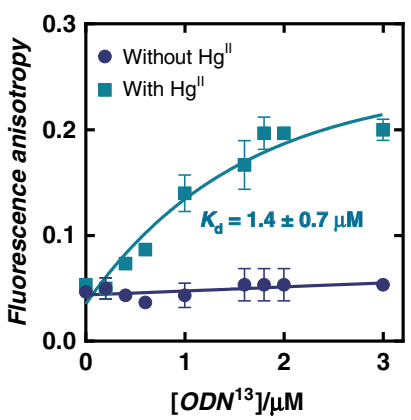

b

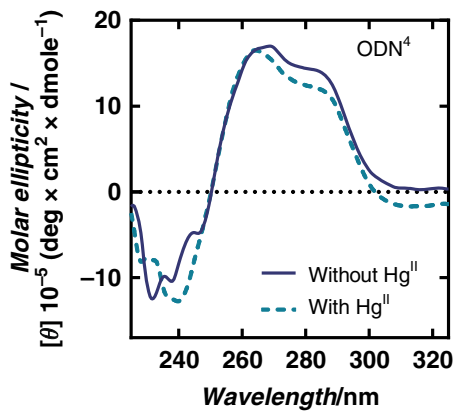

C

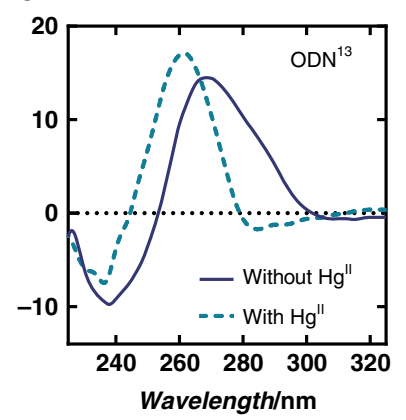

Fig. 8 Fluorescence anisotropy and CD spectra reveal global B-form to A-form helical transition upon addition of Hg"l. a Changes in fluorescence anisotropy $\left(\lambda_{\mathrm{ex}}=480 \mathrm{~nm}, \lambda_{\mathrm{em}}=515 \mathrm{~nm}\right)$ of Neo-BODIPY $(40 \mathrm{nM})$ upon addition of hairpin ODN 13 prepared in the presence (light blue) and absence (dark blue) of $\mathrm{Hg}{ }^{\prime l}$. The values represent mean and standard deviation of three independent measurements. C-Hgll-T base pairs were formed by pre-incubation of the

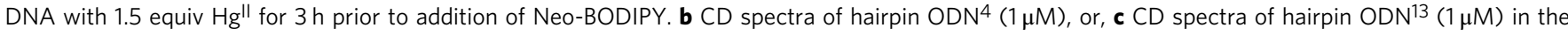
presence and absence of 1.5 equiv of $\mathrm{Hg}^{\prime \prime}$. All samples were prepared in an aqueous buffer containing $200 \mathrm{mM} \mathrm{NaClO} 4$ and $50 \mathrm{mM}$ cacodylic acid ( $\mathrm{pH}=$ 7.8). The number of $\mathrm{Hg}^{\prime \prime}$ equiv are relative to the number of mismatches present. Source data are provided as a Source Data file 
The forward and reverse rate constants of this process were $\sim 10^{3}$ fold faster than dissociation of $\mathrm{Hg}^{\mathrm{II}}$ from $\mathrm{C}-\mathrm{Hg}^{\mathrm{II}}$ - $\mathrm{T}$ base pairs ${ }^{51}$. The HgII ions therefore remained bound to the DNA during multiple structural exchanges. Given the high quality of the structures and dynamics reported here, this system provides a highly attractive model for the development of molecular dynamics simulations aimed at elucidating the pathways of dynamic conformation exchange processes ${ }^{80}$.

Consistent with our structure of the minor duplex (Figs. 4, 5), crystals of a short, A-form DNA sequence also contained two $\mathrm{C}-\mathrm{Hg}^{\mathrm{II}}-\mathrm{T}$ base pairs having $(\mathrm{N} 3) \mathrm{T}_{-} \mathrm{Hg}^{\mathrm{II}}-(\mathrm{N} 4) \mathrm{C}$ connectivity ${ }^{50}$. However, the global A-form structure observed in the crystal structure was inconsistent with our circular dichroism (CD) data collected in solution using five different, slightly longer (14 to 21-mer) duplexes containing one or two $\mathrm{C}-\mathrm{Hg}^{\mathrm{II}}$ - $\mathrm{T}$ base pairs ${ }^{51}$. Together with the observation that (N3)T-HgII-(N3)C binding present in our major structure is associated with more B-form character, and the $(\mathrm{N} 3) \mathrm{T}-\mathrm{Hg}^{\mathrm{II}}-(\mathrm{N} 4) \mathrm{C}$ present in the minor structure is associated with more A-form character, a general picture is suggested. (N3)T-HgII-(N3)C binding and B-form structure is likely dominant in most DNA sequences, in direct analogy with high resolution structures of $\mathrm{T}-\mathrm{Hg}^{\mathrm{II}}-\mathrm{T}$ base pairs ${ }^{49}$. However, the 10 -fold larger ${ }^{1} J$ coupling constants $\left({ }^{15} \mathrm{~N},{ }^{199} \mathrm{Hg}\right)$ observed for $(\mathrm{N} 4) \mathrm{C}-\mathrm{Hg}^{\mathrm{II}}(1052 \mathrm{~Hz})$ connectivity in the minor duplex as compared to the $(\mathrm{N} 3) \mathrm{C}-\mathrm{Hg}^{\mathrm{II}}(114 \mathrm{~Hz})$ in the major structure indicate that stronger nucleobase-metal-nucleobase binding interactions are present in the minor structure. The minor duplex, however, also exhibits a greater degree of structural perturbation away from a canonical B-form duplex that likely destabilizes the complex as compared to the major form. The lower bonding energy of $(\mathrm{N} 3) \mathrm{T}-\mathrm{Hg}^{\mathrm{II}}-(\mathrm{N} 3) \mathrm{C}$ versus $(\mathrm{N} 3) \mathrm{T}-\mathrm{Hg}^{\mathrm{II}}-$ (N4)C is therefore compensated by the overall higher stability of $\mathrm{B}$-form versus $\mathrm{A}$-form in the major and minor structures, respectively. However, in situations that favour A-form (crystallization, dehydration, G/C-rich DNA sequences, etc.) the stronger (N3) T-HgII-(N4)C coordination mode can dominate. The exact causal relationship between global helical conformation and metallo-base pair connectivity is currently unclear. An X-ray study involving a short A-form DNA containing two (N3)T- $\mathrm{Hg}^{\mathrm{II}}$ (N4)C base pairs suggested the combined effects of base pair geometry, neighbouring base effects, and a bridging water molecule in the minor groove were invovled ${ }^{50}$.

For both of our metal-bound structures in solution, the amount of A-form character was greatest in the centre of each helix, suggesting a medium-range influence of $\mathrm{C}-\mathrm{Hg}^{\mathrm{II}}$ - $\mathrm{T}$ formation. In contrast, the opposite pattern was observed in the structure of the metal-free duplex, having the greatest B-form characteristics in the centre of the helix. Together with the long-range coupling ( $>20 \AA$ ) between the two metallo-base pairs via a global conformational exchange, these results suggested that placing numerous $\mathrm{C}-\mathrm{T}$ mismatches throughout a repetitive duplex sequence could support a global B-form $\rightarrow$ A-from helical transition upon addition of stoichiometric $\mathrm{Hg}^{\mathrm{II}}$. Indeed, we were able to identify one such sequence exhibiting a fully-reversible switching cycle from B- to A-form, and A-form to B-form by tandem additions of $\mathrm{Hg}^{\mathrm{II}}$ and $\mathrm{N}$-acetylcysteine (Supplementary Fig. 49). Both transitions were complete in $<30 \mathrm{~s}$, and could be repeated more than 10 times. While numerous examples of local A-form perturbations caused by DNA-protein and DNA-small molecule binding interactions have previously been reported ${ }^{3-9}$, the previous examples of global B-form $\rightarrow$ A-from helical transitions involved global dehydration of the duplex ${ }^{1,2,78}$. Here the global B- to A-form helical transition was a result of discrete, reversible metal binding. In addition to its broad implications in structural biology and biochemistry, this type of A/B-form helical switching can be potentially be utilized in the development of advanced DNA-based materials and devices ${ }^{24-31}$.

\section{Methods}

Sample preparation. For Fig. 2, duplex DNA $(0.3 \mathrm{mM})$ was prepared by dissolving $0.6 \mathrm{mM}$ of the self-complementary sequence in an aqueous solution of $\mathrm{NaClO}_{4}$ ( $50 \mathrm{mM}, 90: 10 \mathrm{H}_{2} \mathrm{O} / \mathrm{D}_{2} \mathrm{O}$ ) and the $\mathrm{pH}$ was adjusted to $\mathrm{pH}=7.8$ by addition of an aqueous solution of $\mathrm{NaOH}$. The sample was annealed by heating to $95^{\circ} \mathrm{C}$ for $5 \mathrm{~min}$ and slow cooling to room temperature over 4 h. For Figs. 3, 4, 7, duplex DNA (0.5-1.0 mM) was prepared by dissolving $1.0 \mathrm{mM}$ or $2.0 \mathrm{mM}$ of the selfcomplementary sequence in aqueous buffer $\left(200 \mathrm{mM} \mathrm{NaClO}_{4}, 50 \mathrm{mM}\right.$ cacodylic acid in $\mathrm{H}_{2} \mathrm{O} / \mathrm{D}_{2} \mathrm{O}(9: 1)$ at $\left.\mathrm{pH}=7.0\right)$, heating to $95^{\circ} \mathrm{C}$ for $5 \mathrm{~min}$, and slowly cooling to room temperature over $4 \mathrm{~h}$. $\mathrm{Hg}\left(\mathrm{ClO}_{4}\right)_{2}$ was added, and the $\mathrm{pH}$ adjusted to $\mathrm{pH} \approx 7.8$ by addition of an aqueous solution of $\mathrm{NaOH}$. For Figs. 5, 6, duplex DNA $(0.4 \mathrm{mM})$ was prepared by dissolving $0.8 \mathrm{mM}$ of the self-complementary sequence in an aqueous solution of $\mathrm{NaClO}_{4}\left(50 \mathrm{mM}, 90: 10 \mathrm{H}_{2} \mathrm{O} / \mathrm{D}_{2} \mathrm{O}\right)$ and the $\mathrm{pH}$ was adjusted to $\mathrm{pH}=7.8$ by addition of an aqueous solution of $\mathrm{NaOH}$. The samples were annealed as described above, mixed with $\mathrm{Hg}^{\mathrm{II}}$ (1.5 equiv with respect to mismatch), the $\mathrm{pH}$ re-adjusted to $\mathrm{pH} \approx 7.8$, and the sample was treated with Chelex-100 (BIO-RAD) for $10 \mathrm{~min}$ to remove excess $\mathrm{Hg}^{\mathrm{II} 43}$. Samples measured in $\mathrm{D}_{2} \mathrm{O}$ were prepared the same way and then lyophilized, dissolved in $99.9 \% \mathrm{D}_{2} \mathrm{O}$ and the $\mathrm{pD}$ was adjusted to $\sim 7.4$ by addition of a solution of $\mathrm{NaOD}$ in $99.9 \% \mathrm{D}_{2} \mathrm{O}$. Samples measured at $4{ }^{\circ} \mathrm{C}$ were equilibrated at $4{ }^{\circ} \mathrm{C}$ for $15 \mathrm{~min}$ prior to measuring.

NMR spectra measurements. ${ }^{1} \mathrm{H}$ NMR spectra were recorded on a Bruker Avance II $500 \mathrm{MHz}$ spectrometer equipped with a TXI $z$-axis gradient probe head using excitation sculpting for water suppression. Proton chemical shifts were referenced to the water line at $4.70 \mathrm{ppm}$. The spectra were processed with a line broadening factor of $10 \mathrm{~Hz}$. 1D ${ }^{15} \mathrm{~N}-\mathrm{NMR}$ spectra were recorded on a Bruker Avance II $500 \mathrm{MHz}$ spectrometer equipped with a BBO $z$-axis gradient CryoProbe at $4{ }^{\circ} \mathrm{C}$ or $25^{\circ} \mathrm{C}$ using either inverse gated or no proton decoupling. The spectra were processed with a line-broadening factor of $10 \mathrm{~Hz}$. $\left[{ }^{15} \mathrm{~N},{ }^{1} \mathrm{H}\right]-\mathrm{HSQC}$ spectra were recorded at $4{ }^{\circ} \mathrm{C}$ or $25^{\circ} \mathrm{C}$ on a Bruker Avance II $500 \mathrm{MHz}$ spectrometer equipped with a BBO $z$-axis gradient CryoProbe, Bruker Avance $600 \mathrm{MHz}$ spectrometer equipped with TCI $z$-axis gradient CryoProbe or on a Bruker Avance $700 \mathrm{MHz}$ spectrometer equipped with TXI $z$-axis gradient CryoProbe. The INEPT times were set to select for a $90 \mathrm{~Hz}$ coupling for ${ }^{1} J\left[{ }^{15} \mathrm{~N},{ }^{1} \mathrm{H}\right]-\mathrm{HSQC}$ 's, $20 \mathrm{~Hz}$ coupling for long-range $\left[{ }^{15} \mathrm{~N},{ }^{1} \mathrm{H}\right]$-HSQC spectra, and to $25 \mathrm{~Hz}$ for band-selective longrange $\left[{ }^{15} \mathrm{~N},{ }^{1} \mathrm{H}\right]$-HSQCs. Water flip-back pulses together with the WATERGATE method were used for water suppression. Proton chemical shifts were referenced to the water line at $4.70 \mathrm{ppm}$ at $4{ }^{\circ} \mathrm{C}$ and ${ }^{15} \mathrm{~N}$ chemical shifts were indirectly referenced against ${ }^{1} \mathrm{H}$ using $\Xi=0.101329118^{81}$. For solution structure determination, non-exchangeable resonances were assigned from $\left[{ }^{1} \mathrm{H},{ }^{1} \mathrm{H}\right]$-NOESY spectra measured in $\mathrm{D}_{2} \mathrm{O}\left(4^{\circ} \mathrm{C}\right.$ and $25^{\circ} \mathrm{C}$ and mixing times of $60 \mathrm{~ms}$ and $\left.250 \mathrm{~ms}\right)$. Exchangeable protons were assigned from $\left[{ }^{1} \mathrm{H},{ }^{1} \mathrm{H}\right]$-NOESY spectra measured in $\mathrm{H}_{2} \mathrm{O} / \mathrm{D}_{2} \mathrm{O}(90: 10)\left(4^{\circ} \mathrm{C}, 150 \mathrm{~ms}\right.$ mixing time). Spectra were recorded on a Bruker Avance $600 \mathrm{MHz}$ spectrometer equipped with a TCI $z$-axis gradient CryoProbe or on a Bruker Avance $700 \mathrm{MHz}$ spectrometer equipped with TXI $z$-axis gradient CryoProbe. For additional information see supporting information.

NMR solution structure calculations. The integrated peak volumes from a representative $\left[{ }^{1} \mathrm{H},{ }^{1} \mathrm{H}\right]$-NOESY spectrum (mixing time $=250 \mathrm{~ms}$ ) measured at $25^{\circ} \mathrm{C}$ were calibrated to distances using CALIBA macro in DYANA ${ }^{82}$. The NOE signals were grouped into four categories: (i) strong (1.8-3.0 Å), (ii) medium (1.8-4.5 $\AA$ ), (iii) weak (3.0-6.0 $\AA)$, and very weak (4.0-7.0 ̊). Structure calculations were performed with XPLOR-NIH 2.46 using standard implemented force field parameters $^{83}$. For introduced restraints for the calculations see supporting information. Starting from a strand generated based on the sequence of nucleoside residues, 2000 structures were calculated based on NOE-, dihedral-, planarity-, and $\mathrm{H}$-bond distance restraints using simulated annealing. The 20 lowest energy structures were selected and used for further refinement using additional RAMA and ORIE database terms. 200 refined structures were calculated and the 20 lowest energy structures were visualized and analyzed. Root mean square deviation (r.m.s. d.) were calculated using MOLMOL ${ }^{84}$ and duplexes were visualized using PyMOL ${ }^{85}$. Base-pair parameters were determined using Curves $+{ }^{86}$ or $3 \mathrm{DNA}^{87}$.

\section{Data availability}

Structures of the metal free (PDB 6RLS), $\mathrm{Hg}^{\mathrm{II}}$-bound major (PDB 6FY6) and $\mathrm{Hg}^{\mathrm{II}}$-bound minor (PDB 6FY7) duplex structures have been deposited in the Protein Data Bank (https:// www.rcsb.org/). All other data generated and analyzed in this study are included in this article, supplementary information, source data file, and are also available from the authors upon reasonable request. Source data for Table 1, Table 2, Figs. 6, 7, 8, and Supplementary Figs. 15, 19-22, 28, 29, 31, 33-35, 39-44, 45, 47, 49 are provided in the Source Data file.

Received: 16 October 2018; Accepted: 5 September 2019; Published online: 23 October 2019 


\section{References}

1. Franklin, R. E. \& Gosling, R. G. The structure of sodium thymonucleate fibres. I. The influence of water content. Acta Crystallogr. 6, 673-677 (1953).

2. DiMaio, F. et al. A virus that infects a hyperthermophile encapsidates A-form DNA. Science 348, 914-917 (2015).

3. Kulkarni, M. \& Mukherjee, A. Sequence dependent free energy profiles of localized B- to A-form transition of DNA in water. J. Chem. Phys. 139, 155102 (2013).

4. van Dam, L., Korolev, N. \& Nordenskiöld, L. Polyamine-nucleic acid interactions and the effects on structure in oriented DNA fibers. Nucleic Acids Res. 30, 419-428 (2002).

5. Barbieri, C. M. et al. Aminoglycoside complexation with a DNA.RNA hybrid duplex: the thermodynamics of recognition and inhibition of RNA processing enzymes. J. Am. Chem. Soc. 125, 6469-6477 (2003).

6. Arya, D. P., Xue, L. \& Willis, B. Aminoglycoside (neomycin) preference is for A-form nucleic acids, not just RNA: results from a competition dialysis study. J. Am. Chem. Soc. 125, 10148-10149 (2003).

7. Robinson, H. \& Wang, A. H.-J. Neomycin, spermine and hexaamminecobalt (III) share common structural motifs in converting B- to A-DNA. Nucleic Acids Res. 24, 676-682 (1996).

8. Vrána, O., Mašek, V., Dražan, V. \& Brabec, V. Raman spectroscopy of DNA modified by intrastrand cross-links of antitumor cisplatin. J. Struct. Biol. 159, 1-8 (2007)

9. Todd, R. C. \& Lippard, S. J. Structure of duplex DNA containing the cisplatin $1,2-\left\{\mathrm{Pt}\left(\mathrm{NH}_{3}\right)_{2}\right\}^{2+}-\mathrm{d}(\mathrm{GpG})$ cross-link at $1.77 \AA$ resolution. J. Inorg. Biochem. 104, 902-908 (2010).

10. Lippert, B. Multiplicity of metal ion binding patterns to nucleobases. Coord. Chem. Rev. 200-202, 487-516 (2000).

11. Gray, R. D. \& Chaires, J. B. Kinetics and mechanism of $\mathrm{K}+-$ and $\mathrm{Na}+$-induced folding of models of human telomeric DNA into G-quadruplex structures. Nucleic Acids Res. 36, 4191-4203 (2008).

12. Šket, P. \& Plavec, J. Tetramolecular DNA quadruplexes in solution: Insights into structural diversity and cation movement. J. Am. Chem. Soc. 132, 12724-12732 (2010).

13. Bugaut, A., Murat, P. \& Balasubramanian, S. An RNA hairpin to Gquadruplex conformational transition. J. Am. Chem. Soc. 134, 19953-19956 (2012)

14. Mirihana Arachchilage, G., Dassanayake, A. C. \& Basu, S. A potassium iondependent RNA structural switch regulates human pre-miRNA $92 \mathrm{~b}$ maturation. Chem. Biol. 22, 262-272 (2015).

15. Pandey, S., Agarwala, P., Jayaraj, G. G., Gargallo, R. \& Maiti, S. The RNA stem-loop to G-quadruplex equilibrium controls mature MicroRNA production inside the cell. Biochemistry 54, 7067-7078 (2015).

16. Kuo, M. H. J. et al. Conformational transition of a hairpin structure to Gquadruplex within the WNT1 gene promoter. J. Am. Chem. Soc. 137, 210-218 (2015).

17. Breaker, R. R. \& Joyce, G. F. A DNA enzyme that cleaves RNA. Chem. Biol. 1, 223-229 (1994).

18. Liu, H. et al. Crystal structure of an RNA-cleaving DNAzyme. Nat. Commun. 8, 1-10 (2017)

19. Wedekind, J. E. \& McKay, D. B. Crystal structure of a lead-dependent ribozyme revealing metal binding sites relevant to catalysis. Nat. Struct. Mol. Biol. 6, 261-268 (1999).

20. Zivarts, M., Liu, Y. \& Breaker, R. R. Engineered allosteric ribozymes that respond to specific divalent metal ions. Nucleic Acids Res. 33, 622-631 (2005).

21. Dann, C. E. 3rd et al. Structure and mechanism of a metal-sensing regulatory RNA. Cell 130, 878-892 (2007).

22. Furukawa, K. et al. Bacterial riboswitches cooperatively bind $\mathrm{Ni}(2+)$ or $\mathrm{Co}(2+)$ ions and control expression of heavy metal transporters. Mol. Cell 57, 1088-1098 (2015).

23. Wedekind, J. E., Dutta, D., Belashov, I. A. \& Jenkins, J. L. Metalloriboswitches: RNA-based inorganic ion sensors that regulate genes. J. Biol. Chem. 292, 9441-9450 (2017).

24. Liu, J. \& Lu, Y. Rational design of 'turn-on' allosteric DNAzyme catalytic beacons for aqueous mercury ions with ultrahigh sensitivity and selectivity. Angew. Chem. Int. Ed. 46, 7587-7590 (2007).

25. Park, K. S., Jung, C. \& Park, H. G. 'Illusionary' polymerase activity triggered by metal ions: Use for molecular logic-gate operations. Angew. Chem. Int. Ed. 49, 9757-9760 (2010).

26. Thomas, J. M., Yu, H. Z. \& Sen, D. A mechano-electronic DNA switch. J. Am. Chem. Soc. 134, 13738-13748 (2012).

27. Mor-Piperberg, G., Tel-Vered, R., Elbaz, J. \& Willner, I. Nanoengineered electrically contacted enzymes on DNA scaffolds: Functional assemblies for the selective analysis of $\mathrm{Hg}^{2+}$ Ions. J. Am. Chem. Soc. 132, 6878-6879 (2010).

28. Wang, Z. G., Elbaz, J. \& Willner, I. DNA machines: Bipedal walker and stepper. Nano Lett. 11, 304-309 (2011)

29. Wen, S. et al. Highly sensitive and selective DNA-based detection of mercury (II) with $\alpha$-hemolysin nanopore. J. Am. Chem. Soc. 133, 18312-18317 (2011).
30. Hong, T. et al. Selective detection of N6-methyladenine in DNA via metal ion mediated replication and rolling circle amplification. Chem. Sci. 8, 200-205 (2017).

31. Guo, X. \& Seela, F. Anomeric 2'-deoxycytidines and silver ions: hybrid base pairs with greatly enhanced stability and efficient DNA mismatch detection with a-dC. Chem. Eur. J. 23, 11776-11779 (2017).

32. Ono, A., Torigoe, H., Tanaka, Y. \& Okamoto, I. Binding of metal ions by pyrimidine base pairs in DNA duplexes. Chem. Soc. Rev. 40, 5855-5866 (2011).

33. Takezawa, Y. \& Shionoya, M. Metal-mediated DNA base pairing: Alternatives to hydrogen-bonded Watson-Crick base pairs. Acc. Chem. Res. 45, 2066-2076 (2012).

34. Lippert, B. \& Sanz Miguel, P. J. The renaissance of metal-pyrimidine nucleobase coordination chemistry. Acc. Chem. Res. 49, 1537-1545 (2016)

35. Jash, B. \& Müller, J. Metal-mediated base pairs: from characterization to application. Chem. Eur. J. 23, 17166-17178 (2017).

36. Takezawa, Y., Müller, J. \& Shionoya, M. Chem. Lett. 46, 622-633 (2017).

37. Kondo, J. et al. A metallo-DNA nanowire with uninterrupted one-dimensional silver array. Nat. Chem. 9, 956-960 (2017).

38. Katz, S. Mechanism of the reaction of polynucleotides and $\mathrm{Hg}^{\mathrm{II}}$. Nature 194 569 (1962).

39. Katz, S. The reversible reaction of $\mathrm{Hg}$ (II) and double-stranded polynucleotides a step-function theory and its significance. Biochim. Biopyhs. Acta 68, 240-253 (1963).

40. Yamane, T. \& Davidson, N. On the complexing of desoxyribonucleic acid (DNA) by mercuric ion. J. Am. Chem. Soc. 83, 2599-2607 (1961).

41. Miyake, Y. et al. Mercury ${ }^{\mathrm{II}}$-mediated formation of thymine- $\mathrm{Hg}^{\mathrm{II}}$-thymine base pairs in DNA duplexes. J. Am. Chem. Soc. 128, 2172-2173 (2006).

42. Torigoe, H., Ono, A. \& Kozasa, T. HgII ion specifically binds with T:T mismatched base pair in duplex DNA. Chem. Eur. J. 16, 13218-13225 (2010)

43. Schmidt, O. P., Mata, G. \& Luedtke, N. W. Fluorescent base analogue reveals $\mathrm{T}-\mathrm{Hg}^{\mathrm{II}}-\mathrm{T}$ base pairs have high kinetic stabilities that perturb DNA metabolism. J. Am. Chem. Soc. 138, 14733-14739 (2016).

44. Urata, H., Yamaguchi, E., Funai, T., Matsumura, Y. \& Wada, S. I. Incorporation of thymine nucleotides by DNA polymerases through $\mathrm{T}-\mathrm{Hg}_{\mathrm{II}} \mathrm{T}$ base pairing. Angew. Chem. Int. Ed. 49, 6516-6519 (2010).

45. Cantoni, O., Christie, N. T., Swann, A., Drath, D. B. \& Costa, M. Mechanism of $\mathrm{HgCl}_{2}$ cytotoxicity in cultured mammalian cells. Mol. Pharmacol. 26, 360-368 (1984)

46. Tanaka, Y. et al. ${ }^{15} \mathrm{~N}-{ }^{15} \mathrm{~N}$ J-coupling across $\mathrm{Hg}^{\mathrm{II}}$ : Direct observation of $\mathrm{Hg}^{\mathrm{II}}$ mediated T-T base pairs in a DNA duplex. J. Am. Chem. Soc. 129, 244-245 (2007).

47. Dairaku, T. et al. Structure determination of an $\mathrm{Ag}^{\mathrm{I}}$-mediated cytosinecytosine base pair within DNA duplex in solution with ${ }^{1} \mathrm{H} /{ }^{15} \mathrm{~N} /{ }^{109} \mathrm{Ag}$ NMR spectroscopy. Chem. Eur. J. 22, 13028-13031 (2016).

48. Yamaguchi, H. et al. The structure of metallo-DNA with consecutive thymine$\mathrm{Hg}^{\mathrm{II}}$-thymine base pairs explains positive entropy for the metallo base pair formation. Nucleic Acids Res. 42, 4094-4099 (2014).

49. Kondo, J. et al. Crystal structure of metallo DNA duplex containing consecutive Watson-Crick-like T-HgII-T base pairs. Angew. Chem. Int. Ed. 53 2385-2388 (2014)

50. Liu, H. et al. Flexibility and stabilization of $\mathrm{Hg}^{\mathrm{II}}$-mediated $\mathrm{C}: \mathrm{T}$ and $\mathrm{T}: \mathrm{T}$ base pairs in DNA duplex. Nucleic Acids Res. 45, 2910-2918 (2017).

51. Schmidt, O. P., Benz, A. S., Mata, G. \& Luedtke, N. W. HgI binds to C-T mismatches with high affinity. Nucleic Acids Res. 46, 6470-6479 (2018).

52. Allawi, H. T. \& SantaLucia, J. Thermodynamics of internal C.T mismatches in DNA. Nucleic Acids Res. 26, 2694-2701 (1998).

53. Boulard, Y., Cognet, J. A. H. \& Fazakerley, G. V. Solution structure as a function of $\mathrm{pH}$ of two central mismatches, C.T and C.C, in the 29 to $39 \mathrm{~K}$-ras gene sequence, by nuclear magnetic resonance and molecular dynamics. $J$. Mol. Biol. 268, 331-347 (1997).

54. Gaffney, B. L. \& Jones, R. A. Thermodynamic comparison of the base pairs formed by the carcinogenic lesion $\mathrm{O}^{6}$-methylguanine with reference both to Watson-Crick pairs and to mismatched pairs. Biochemistry 28, 5881-5889 (1989).

55. Aboul-ela, F., Koh, D., Tinoco, I. \& Martin, F. H. Base-base mismatches. Thermodynamics of double helix formation for $\mathrm{dCA}_{3} \mathrm{XA}_{3} \mathrm{G}+\mathrm{dCT}_{3} \mathrm{YT}_{3} \mathrm{G}(\mathrm{X}$ $\mathrm{Y}=$ A,C,G,D. Nucleic Acids Res. 13, 4811-4824 (1985).

56. Tanaka, Y. \& Ono, A. Nitrogen-15 NMR spectroscopy of $N$-metallated nucleic acids: insights into ${ }^{15} \mathrm{~N}$ NMR parameters and N-metal bonds. Dalt. Trans. $\mathbf{0}$, 4965-4974 (2008)

57. Dairaku, T. et al. Direct detection of the mercury-nitrogen bond in the thymine-HgII-thymine base-pair with ${ }^{199} \mathrm{Hg}$ NMR spectroscopy. Chem Commun. 51, 8488-8491 (2015)

58. Stephen Reid, R. \& Podányi, B. A proton NMR study of the glycine-mercury (II) system in aqueous solution. J. Inorg. Biochem. 32, 183-195 (1988)

59. Krumm, M. et al. Mixed platinum(II)-mercury(II) cytosine nucleobase complexes with metal-metal Bonds. Inorg. Chem. 32, 2183-2189 (1993). 
60. Charland, J. P., Phan Viet, M. T., St-Jacques, M. \& Beauchamp, A. L. Multinuclear NMR study of the disproportionation and syn/anti isomerism in solutions of amino-substituted methylmercury derivatives of adenine and 9methyladenine. J. Am. Chem. Soc. 107, 8202-8211 (1985).

61. Davies, D. B. Conformations of nucleosides and nucleotides. Prog. Nucl. Magn. Reson. Spectrosc. 12, 135-225 (1978).

62. Hosur, R. V. et al. Solution structure of d-GAATTCGAATTC by 2D NMR. A new approach to determination of sugar geometries in DNA segments. FEBS Lett. 205, 71-76 (1986).

63. Gyi, J. I., Lane, A. N., Conn, G. L. \& Brown, T. Solution structures of DNA.RNA hybrids with purine-rich and pyrimidine-rich strands: Comparison with the homologous DNA and RNA duplexes. Biochemistry 37, 73-80 (1998).

64. Clay, M. C., Ganser, L. R., Merriman, D. K. \& Al-Hashimi, H. M. Resolving sugar puckers in RNA excited states exposes slow modes of repuckering dynamics. Nucleic Acids Res. 45, e134 (2017)

65. Szyperski, T. et al. NMR structure of the chimeric hybrid duplex r(gcaguggc).r (gcca)d(CTGC) comprising the tRNA-DNA junction formed during initiation of HIV-1 reverse transcription. J. Biomol. NMR 13, 343-355 (1999).

66. Drew, H. R. et al. Structure of a B-DNA dodecamer: conformation and dynamics. Proc. Natl Acad. Sci. USA 78, 2179-2183 (1981).

67. Gao, X. \& Jeffs, P. W. Sequence-dependent conformational heterogeneity of a hybrid DNA.RNA dodecamer duplex. J. Biomol. NMR 4, 367-384 (1994).

68. Roberts, G. C. K. NMR of macromolecules. (Oxford University Press, 1993).

69. Farrow, N. A., Zhang, O., Forman-Kay, J. D. \& Kay, L. E. A heteronuclear correlation experiment for simultaneous determination of ${ }^{15} \mathrm{~N}$ longitudinal decay and chemical exchange rates of systems in slow equilibrium. J. Biomol. NMR 4, 727-734 (1994).

70. Guilbaud, S., Salomé, L., Destainville, N., Manghi, M. \& Tardin, C. Dependence of DNA persistence length on ionic strength and ion type. Phys. Rev. Lett. 122, 028102 (2019).

71. Zhang, $\mathrm{H}$. et al. Effects of $\mathrm{pH}$ on oxaliplatin-induced condensation of single DNA molecules. Chin. Phys. Lett. 31, 028701 (2014).

72. Štefl, R. et al. A-like guanine-guanine stacking in the aqueous DNA duplex of d(GGGGCCCC). J. Mol. Biol. 307, 513--5524 (2001).

73. Tsai, A. G. et al. Conformational variants of duplex DNA correlated with cytosine-rich chromosomal fragile sites. J. Biol. Chem. 284, 7157-7164 (2009).

74. Watkins, D., Gong, C., Kellish, P. \& Arya, D. P. Probing A-form DNA: A fluorescent aminosugar probe and dual recognition by anthraquinoneneomycin conjugates. Bioorg. Med. Chem. 25, 1309-1319 (2017).

75. Nakano, M., Moody, E. M., Liang, J. \& Bevilacqua, P. C. Selection for thermodynamically stable DNA tetraloops using temperature gradient gel electrophoresis reveals four motifs: d(cGNNAg), d(cGNABg), d(cCNNGg), and $\mathrm{d}(\mathrm{gCNNGc})$. Biochemistry 41, 14281-14292 (2002).

76. Luedtke, N. W., Carmichael, P. \& Tor, Y. Cellular uptake of aminoglycosides, guanidinoglycosides, and poly-arginine. J. Am. Chem. Soc. 125, 12374-12375 (2003).

77. Luedtke, N. W., Liu, Q. \& Tor, Y. RNA-ligand interactions: affinity and specificity of aminoglycoside dimers and acridine conjugates to the HIV-1 rev response element. Biochemistry 42, 11391-11403 (2003).

78. Kypr, J., Kejnovská, I., Bednářová, K. \& Vorlíčková, M. Circular dichroism spectroscopy of nucleic acids. Compr. Chiropt. Spectrosc. 2, 575-586 (2012)

79. Johannsen, S., Megger, N., Böhme, D., Sigel, R. K. O. \& Müller, J. Solution structure of a DNA double helix with consecutive metal-mediated base pairs. Nat. Chem. 2, 229-234 (2010).

80. Šponer, J. et al. Molecular dynamics simulations of nucleic acids tetranucleotides ribosome. J. Phys. Chem. Lett. 5, 1771-1782 (2014).

81. Wishart, D. S. et al. ${ }^{1} \mathrm{H},{ }^{13} \mathrm{C}$ and ${ }^{15} \mathrm{~N}$ chemical shift referencing in biomolecular NMR. J. Biomol. NMR 6, 135-140 (1995).

82. Güntert, P., Mumenthaler, C. \& Wüthrich, K. Torsion angle dynamics for NMR structure calculation with the new program DYANA. J. Mol. Biol. 273, 283-298 (1997).
83. Schwieters, C. D., Kuszewski, J. J. \& Marius Clore, G. Using Xplor-NIH for NMR molecular structure determination. Prog. Nucl. Magn. Reson. Spectrosc. 48, 47-62 (2006).

84. Koradi, R., Billeter, M. \& Wüthrich, K. MOLMOL: A program for display and analysis of macromolecular structures. J. Mol. Graph. 14, 51-55 (1996).

85. The PyMOL Molecular Graphics System, Version 2.0.7, Schrödinger, LLC.

86. Lavery, R., Moakher, M., Maddocks, J. H., Petkeviciute, D. \& Zakrzewska, K. Conformational analysis of nucleic acids revisited: Curves. Nucleic Acids Res. 37, 5917-5929 (2009).

87. Lu, X.-J. \& Olson, W. K. 3DNA: A versatile, integrated software system for the analysis, rebuilding and visualization of three-dimensional nucleic-acid structures. Nat. Protoc. 3, 1213-1227 (2008).

88. Frederick, C. A. et al. Molecular structure of an A-DNA decamer d (ACCGGCCGGT). Eur. J. Biochem. 181, 295-307 (1989).

\section{Acknowledgements}

We thank Prof. Oliver Zerbe for critical reading of this manuscript, Dr. Thomas Fox for NMR support, and Dr. Laurent Bigler and Urs Stalder for MS support. We thank Prof. Yitzhak Tor for his generous gift of Neo-BODIPY. Financial support was provided by the University of Zurich and the Swiss National Science Foundation (grant \#165949 to N.W.L.).

\section{Author contributions}

O.S. and N.L. conceived the project. O.S.; S.Ju.; S.Jo.; A.K.; R.S., and N.L. contributed to experimental design and manuscript editing. O.S.; S.Ju.; S.Jo.; and A.K. collected and analysed the data. O.S. and N.L. wrote the manuscript.

\section{Competing interests}

The authors declare no competing interests.

\section{Additional information}

Supplementary information is available for this paper at https://doi.org/10.1038/s41467019-12440-x.

Correspondence and requests for materials should be addressed to N.W.L.

Peer review information Nature Communications thanks Vladimír Sychrovský and the other, anonymous, reviewer(s) for their contribution to the peer review of this work. Peer reviewer reports are available.

Reprints and permission information is available at http://www.nature.com/reprints

Publisher's note Springer Nature remains neutral with regard to jurisdictional claims in published maps and institutional affiliations.

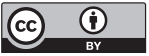

Open Access This article is licensed under a Creative Commons Attribution 4.0 International License, which permits use, sharing, adaptation, distribution and reproduction in any medium or format, as long as you give appropriate credit to the original author(s) and the source, provide a link to the Creative Commons license, and indicate if changes were made. The images or other third party material in this article are included in the article's Creative Commons license, unless indicated otherwise in a credit line to the material. If material is not included in the article's Creative Commons license and your intended use is not permitted by statutory regulation or exceeds the permitted use, you will need to obtain permission directly from the copyright holder. To view a copy of this license, visit http://creativecommons.org/ licenses/by/4.0/.

(C) The Author(s) 2019 